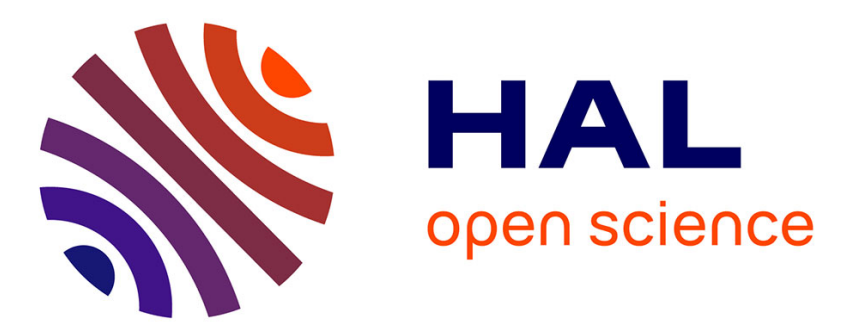

\title{
Experimental evidence of NO SCR mechanism in the presence of the BEA zeolite with framework and extra-framework cobalt species
}

Pawel Boroń, Lucjan Chmielarz, Barbara Gil, Bartosz Marszalek, Stanislaw Dzwigaj

\section{To cite this version:}

Pawel Boroń, Lucjan Chmielarz, Barbara Gil, Bartosz Marszalek, Stanislaw Dzwigaj. Experimental evidence of NO SCR mechanism in the presence of the BEA zeolite with framework and extra-framework cobalt species. Applied Catalysis B: Environmental, 2016, 198, pp.457-470. 10.1016/j.apcatb.2016.06.012 . hal-01329568

\section{HAL Id: hal-01329568 \\ https://hal.sorbonne-universite.fr/hal-01329568}

Submitted on 9 Jun 2016

HAL is a multi-disciplinary open access archive for the deposit and dissemination of scientific research documents, whether they are published or not. The documents may come from teaching and research institutions in France or abroad, or from public or private research centers.
L'archive ouverte pluridisciplinaire HAL, est destinée au dépôt et à la diffusion de documents scientifiques de niveau recherche, publiés ou non, émanant des établissements d'enseignement et de recherche français ou étrangers, des laboratoires publics ou privés. 
Experimental evidence of NO SCR mechanism in the presence of the

\section{BEA zeolite with framework and extra-framework cobalt species}

Paweł Boroñ $^{1,2}$, Lucjan Chmielarz ${ }^{1, *}$, Barbara Gil ${ }^{1}$, Bartosz Marszałek ${ }^{1}$, Stanislaw Dzwigaj ${ }^{2, *}$

${ }^{1}$ Faculty of Chemistry, Jagiellonian University, Ingardena 3, 30-060 Kraków, Poland

${ }^{2}$ Sorbonne Universités, UPMC Univ Paris 06, CNRS, UMR 7197, Laboratoire de Réactivité de

Surface, 4 place Jussieu, Case 168, F-75252, Paris, France

*Corresponding authors:

Lucjan Chmielarz, E-mail: chmielar@ chemia.uj.edu.pl, tel. +48 126632006

Stanislaw Dzwigaj, E-mail: stanislaw.dzwigaj@upmc.fr, tel: +33 144272113 
Graphical abstract

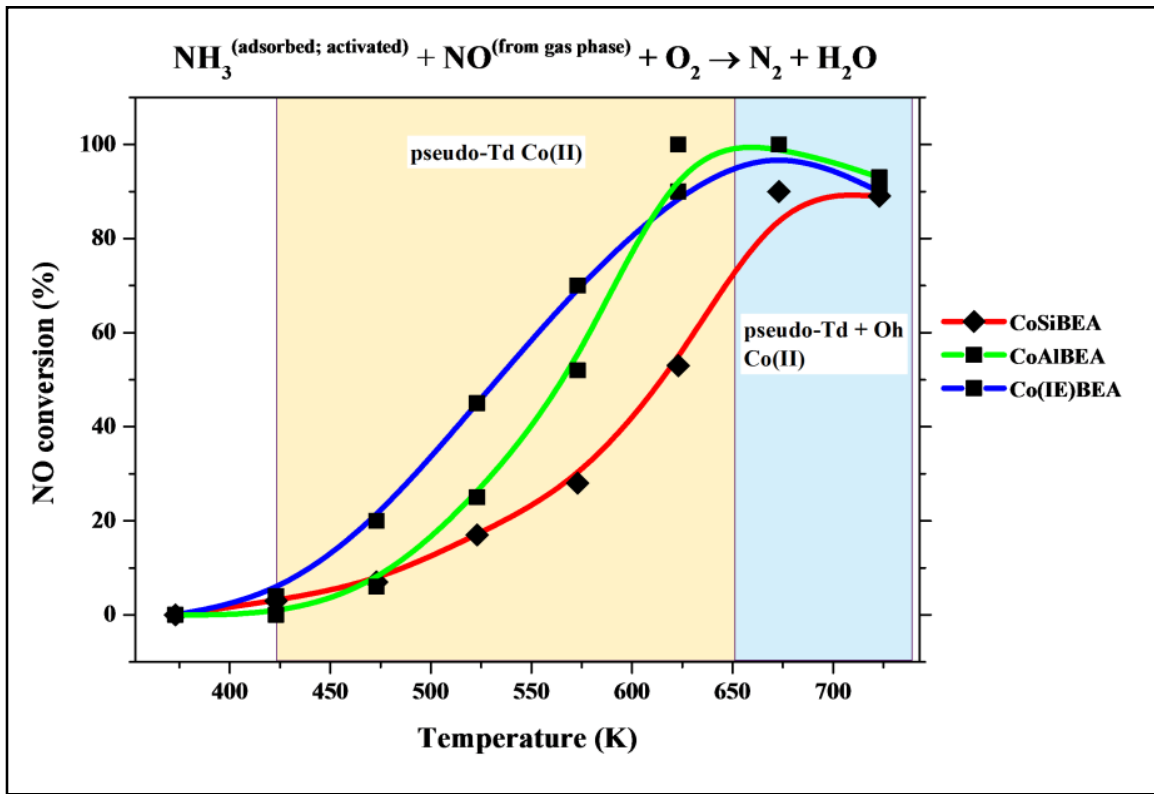

Highlights

- Co introduced in Beta supports effectively activates $\mathrm{NH}_{3}$ for reaction with NO.

- The highest reactivity of ammonia in SCR of NO found for Co(IE)BEA catalyst.

- - During SCR of NO ammonia and NO compete for the same adsorption sites.

- $\quad$ SCR of NO process involves the reaction of chemisorbed $\mathrm{NH}_{3}$ with NO from gas phase.

\section{Abstract}

Temperature-programmed desorption (TPD), temperature-programmed surface reaction (TPSR) and stop flow-TPD techniques as well as FT-IR spectroscopy of pre-adsorbed $\mathrm{NH}_{3}$ and NO are applied to characterize active sites present in Co-containing BEA zeolites. Cobalt is introduced into BEA zeolite by different methods: (i) two-step postsynthesis - PS, (ii) conventional wet impregnation - Imp and (iii) ion exchange - IE. The obtained catalysts are 
labelled as $\mathrm{Co}(\mathrm{PS}) \mathrm{SiBEA}$ (postsynthesis), $\mathrm{Co}$ (IMP)AlBEA (wet impregnation) and Co(IE)AlBEA (ion exchange). All the obtained catalysts are found to be active in the process of selective catalytic reduction (SCR) of NO with ammonia. The catalytic activity depends on the method used for cobalt introduction and thus on cobalt centres speciation. The reactivity of $\mathrm{NH}_{3}$ and NO adsorbed on Co(IMP)AlBEA and Co(IE)AlBEA is higher than that measured for the $\mathrm{Co}(\mathrm{PS}) \mathrm{SiBEA}$ catalysts. The temperature-programmed studies and FT-IR with $\mathrm{NO}$ and/or $\mathrm{NH}_{3}$ adsorption for the Co-containing samples show that during SCR reaction $\mathrm{NO}$ and $\mathrm{NH}_{3}$ molecules compete for the same adsorption sites. The main reaction pathways of the $\mathrm{DeNO}_{\mathrm{x}}$ process performed in the presence of Co(IMP)AlBEA and Co(IE)AlBEA involves the reaction between chemisorbed ammonia and NO from gas phase, according to the Eley-Riedel mechanism.

Keywords: cobalt zeolite, NO, SCR, TPSR, FT-IR

\section{Introduction}

The emission of nitrogen oxides $\left(\mathrm{NO}_{\mathrm{x}}\right)$ from stationary and mobile sources causes serious environmental problems. Ammonia based selective catalytic reduction (SCR) of $\mathrm{NO}_{\mathrm{x}}$ is a widely practiced technology for diesel engine vehicles to reduce $\mathrm{NO}_{\mathrm{x}}\left(\mathrm{NO}, \mathrm{NO}_{2}\right)$ to $\mathrm{N}_{2}$ [1]. In this technique, $\mathrm{NO}_{\mathrm{x}}$ is continuously reduced by $\mathrm{NH}_{3}$ on the $\mathrm{V}_{2} \mathrm{O}_{5} / \mathrm{WO}_{3} / \mathrm{TiO}_{2}$ catalysts $[2,3]$. However, $\mathrm{V}_{2} \mathrm{O}_{5}$-based catalysts have inadequate stability at the higher temperatures encountered in high load vehicle operation and are not suitable for systems including a particulate filter that actively regenerates at higher temperatures. Hence, various catalysts, including noble metals based systems [4], ion-exchanged zeolites [5-9], and metal oxides [10,11] have been extensively studied. However, reaction mechanism, which determines the overall activity of the catalysts, is still a subject of a debate. The standard SCR reaction between $\mathrm{NO}_{\mathrm{x}}$ and $\mathrm{NH}_{3}$ occurs in the presence of oxygen. Several papers analysing the mechanism and the kinetics of the SCR of NO reaction over various zeolite catalysts have been already published [12-20]. It was shown that Co(II) ion-exchanged zeolites, such as Co-ZSM-5 [21-23], Co-ferrierite [24-26], Co-BEA [27,28] and Co-mordenite [29,30], exhibit high activity in the SCR of $\mathrm{NO}_{\mathrm{x}}$. The need for more active and selective catalysts initiated a number of studies focused on understanding the reaction mechanism [31-33]. In order to describe the possible reaction pathways, the reaction surface intermediates 
and the nature of the active sites must be identified. The controversial results published by different authors indicate the complexity of the problem [31,32,34]. It is well known that the $\mathrm{DeNO}_{\mathrm{x}}$ efficiency is greatly related to loading, dispersion and state of cobalt species that are usually influenced by the preparation method, surface acidity related to the Si/Al ratio and type of the zeolite porous structure [35-38]. Tetrahedrally and octahedrally coordinated Co(II) ions are considered as main active sites of the SCR process, while $\mathrm{Co}_{3} \mathrm{O}_{4}$ is reported to be active in hydrocarbons combustion and in $\mathrm{NO}$ to $\mathrm{NO}_{2}$ oxidation [38].

In general, it is postulated that the reduction of NO takes place via the interaction between surface $\mathrm{NO}_{\mathrm{x}}$ species with the reducing agent (e.g. $\mathrm{NH}_{3}$ or $\mathrm{CH}_{4}$ ) to form surface intermediates, which then decompose to the reaction products $[31,32,34,39,40]$. However, the structure of these species is ambiguous. Nitrite-nitrate complexes were postulated as surface $\mathrm{NO}_{\mathrm{x}}$ species by several authors [41,42]. In contrast, Resini et al. [32] proposed that the reaction proceeds through a kind of surface nitrate via a redox mechanism over $\mathrm{Co}(\mathrm{II}) / \mathrm{Co}$ (III) active sites. Lobree et al. [34] substantiated surface nitrile $(\mathrm{CN})$ species as important reaction intermediates. According to Chen [31], the prevailing reaction path involves the reaction of either ammonia or amine intermediate with both $\mathrm{NO}$ and $\mathrm{NO}_{2}$. In catalysts such as Co-ZSM-5, the transition metal species were suggested to play the crucial role in the initiating the reduction of NO [31]. Sun et al. [43] presented a mechanistic model for the metal-exchange zeolite catalysts, in which the preferred path for $\mathrm{NO}_{\mathrm{x}}$ reduction with ammonia occurs via ammonium nitrite, which decomposes to $\mathrm{N}_{2}$ and $\mathrm{H}_{2} \mathrm{O}$. Other studies have suggested that the reduction of $\mathrm{NO}$ and $\mathrm{NO}_{2}$ by $\mathrm{NH}_{3}$ involves the formation of $\mathrm{HNO}_{2}$ and $\mathrm{HNO}_{3}$ [44-47]. It is reported that both $\mathrm{NO}_{\mathrm{x}}$ and $\mathrm{NH}_{3}$ could adsorb on the surface of ion-exchanged zeolites [46,47].

In order to obtain more clear indication concerning the nature of the active species and reaction intermediates involved in the reaction, as well as on the nature of the actual catalyst active sites, spectroscopic and surface reactivity techniques can be applied. It was shown that NO does not adsorb strongly on the catalyst surface, whereas ammonia is strongly adsorbed [48,49]. The SCR NO reaction involves a strongly adsorbed ammonia species and gaseous or weakly bonded NO molecules. Moreover, it was postulated that the rate of the SCR NO reaction depends on the ammonia surface concentration for low $\mathrm{NH}_{3}$ coverage, whereas a much weaker dependence, if any, exists at high ammonia coverage $[48,49]$. In spite of many data resulting from 
experimental studies focused on mechanistic issues and reaction pathways, the SCR mechanism on the Co-BEA zeolite catalysts is still the subject of the debate.

In this study, the Co-containing BEA zeolite catalysts were prepared by different methods: two-step postsynthesis, wet impregnation and conventional ion exchange. The obtained samples exhibited high activity and selectivity in SCR NO with $\mathrm{NH}_{3}$. Thus, the studies of the reaction mechanism for this series of the catalysts were undertaken to determine the role of cobalt species type on catalytic performance of the catalysts.

\section{Experimental}

\subsection{Catalysts preparation}

Three series of Co-containing zeolites were prepared by two-step postsynthesis (PS), conventional wet impregnation (IMP) and ion exchange (IE) procedures.

Co(PS)SiBEA zeolite (with Co loading of $1.0 \mathrm{wt} \%$ ) was prepared by two-step postsynthesis procedure reported earlier [6-9]. In the first step, $2 \mathrm{~g}$ of HAlBEA zeolite, obtained by calcination of tetraethyl-ammonium BEA (TEABEA) zeolite at $823 \mathrm{~K}$ for $15 \mathrm{~h}$ provided by RIPP (China) was treated with $13 \mathrm{~mol} \mathrm{~L}^{-1} \mathrm{HNO}_{3}$ solution under stirring $(353 \mathrm{~K}, 4 \mathrm{~h}$ ) to remove aluminium from the zeolite structure. In the second step, $2 \mathrm{~g}$ of resulting SiBEA obtained after filtration were dispersed in aqueous solutions $(\mathrm{pH}=2.8)$ containing $1.7 \cdot 10^{-3} \mathrm{~mol} \mathrm{~L}^{-1}$ of $\mathrm{Co}\left(\mathrm{NO}_{3}\right)_{2} \cdot 6 \mathrm{H}_{2} \mathrm{O}$ and stirred at room temperature for $24 \mathrm{~h}$. Then, the obtained suspensions were stirred in evaporator under vacuum of a water pump in air at $353 \mathrm{~K}$ for $2 \mathrm{~h}$ until water was evaporated. The solid with the cobalt content of $1.0 \mathrm{wt} \%$ was labelled as Co(PS)SiBEA.

Co(IMP)AlBEA zeolite (with Co loading of $1 \mathrm{wt} \%$ ) was prepared by conventional wet impregnation method. In this case, $2 \mathrm{~g}$ of HAlBEA was dispersed in aqueous solution $(\mathrm{pH}=3.3)$ containing $1.7 \cdot 10^{-3} \mathrm{~mol} \mathrm{~L}-1$ of $\mathrm{Co}\left(\mathrm{NO}_{3}\right)_{2} \cdot 6 \mathrm{H}_{2} \mathrm{O}$ and stirred at room temperature for $24 \mathrm{~h}$. Then, the suspension was stirred in evaporator under vacuum of a water pump at $353 \mathrm{~K}$ for $2 \mathrm{~h}$ in air until water was evaporated. The solid with cobalt content of $1.0 \mathrm{wt} \%$ was labelled as Co(IMP)AlBEA.

Co(IE)AlBEA sample (with Co loading of $1.4 \mathrm{wt} \%$ ) was prepared by ion exchange method. Firstly, tetraethylammonium form of BEA zeolite was calcined ( $823 \mathrm{~K}, 15 \mathrm{~h})$ to obtain HAlBEA. Organic-free BEA was treated two times with a $0.1 \mathrm{~mol} \mathrm{~L}^{-1} \mathrm{NH}_{4} \mathrm{NO}_{3}$ solution at $343 \mathrm{~K}$ for $3 \mathrm{~h}$ in order to exchange $\mathrm{K}^{+}$and $\mathrm{Na}^{+}$ions present in industrial BEA zeolite for $\mathrm{NH}_{4}{ }^{+}$. Then, 
the solid was washed with distilled water, dried overnight at $363 \mathrm{~K}$ and labelled as $\mathrm{NH}_{4} \mathrm{AlBEA}$. The latter was dispersed in a $1.0 \cdot 10^{-2}$ mol L-1 aqueous solution of $\mathrm{Co}\left(\mathrm{NO}_{3}\right)_{2} \cdot 6 \mathrm{H}_{2} \mathrm{O}$ at $343 \mathrm{~K}$ $(\mathrm{pH}=5.2)$. Then, after filtration, washing with distilled water the sample was dried. The obtained sample was labelled as Co(IE)AlBEA.

Before physicochemical characterization and catalytic tests, $\mathrm{Co}(\mathrm{PS}) \mathrm{SiBEA}$, Co(IMP)AlBEA and Co(IE)AlBEA were calcined at $773 \mathrm{~K}$ for $2 \mathrm{~h}$.

\subsection{Catalyst testing}

Co(PS)SiBEA, Co(IMP)AlBEA and Co(IE)AlBEA were studied as catalysts for SCR of NO with ammonia. Catalytic experiments were performed in a fixed-bed flow microreactor system. The reactant concentrations were continuously measured using a quadrupole mass spectrometer RGA 200 Prevac, with Faraday cup (FC) detector, connected directly to the reactor outlet. Sensitivity of the detector is equal $2 \times 10^{-4} \mathrm{~A}_{\text {Torr }^{-1}}$ (measured with $\mathrm{N}_{2} 28$ amu with 1 amu full peak width $10 \%$ height, $70 \mathrm{eV}$ electron energy, $12 \mathrm{eV}$ ion energy and $1 \mathrm{~mA}$ electron emission current). The minimum detectable partial pressure is about $5 \times 10^{-11}$ Torr. Prior to the reaction, each sample $(100 \mathrm{mg})$ of the catalyst was outgassed in a flow of pure helium at $823 \mathrm{~K}$ for $30 \mathrm{~min}$. The following composition of the gas mixture was used: $[\mathrm{NO}]=\left[\mathrm{NH}_{3}\right]=0.25$ vol. \%, $\left[\mathrm{O}_{2}\right]=2.5$ vol. $\%$ and $[\mathrm{He}]=97$ vol. $\%$. The reaction was studied in the temperature range between $373 \mathrm{~K}$ and $723 \mathrm{~K}$. Total flow rate of the reaction mixture was $40 \mathrm{~mL} \mathrm{~min}^{-1}$, with a weight hourly space velocity (WHSV) of about $24.000 \mathrm{~mL} \mathrm{~h}^{-1} \mathrm{~g}^{-1}$.

\subsection{Catalysts characterization}

The obtained zeolite catalysts were characterized with respect to: (i) structure (XRD, FTIR); (ii) texture (low-temperature $\mathrm{N}_{2}$ adsorption) and (iii) coordination and aggregation of deposited cobalt species (DR UV-vis, XPS, TPR). Detailed description of the experimental systems used as well as experimental procedures and analysis of the obtained results can be found in our previous paper [9]. While, in this paper a summary of the catalyst characteristics and the selected examples of the characterization studies are presented.

\subsection{Studies of the reaction mechanism}


The mechanism of the SCR of NO with ammonia over BEA zeolite modified with cobalt species was studied by various temperature-programmed techniques and FT-IR analysis of the samples pre-adsorbed with the reaction substrates $\left(\mathrm{NO}, \mathrm{NH}_{3}\right)$.

\subsubsection{Temperature-programmed desorption}

The temperature-programmed desorption of $\mathrm{NH}_{3}\left(\mathrm{NH}_{3}-\mathrm{TPD}\right)$ or $\mathrm{NO}$ (NO-TPD) were carried out in the temperature range of $343-773 \mathrm{~K}$ in a fix bed continuous flow microreactor system. The reaction temperature was measured by a K-type thermocouple located in a quartz capillary immersed in the catalyst bed. The molecules desorbing from the samples were monitored on-line by a quadrupole mass spectrometer (RGA 200 Prevac) connected to the reactor outlet via a heated line. Before TPD experiments, the zeolite sample $(50 \mathrm{mg})$ was outgassed at $673 \mathrm{~K}$ for $1 \mathrm{~h}$ in a flow of pure helium $\left(20 \mathrm{~mL} \mathrm{~min}^{-1}\right)$. Subsequently, the sample was cooled down to $343 \mathrm{~K}$ and saturated for about $30 \mathrm{~min}$ in a flow of 1 vol. $\% \mathrm{NH}_{3}$ diluted in $\mathrm{He}$ or 1 vol. \% $\mathrm{NO}$ diluted in $\mathrm{He}\left(20 \mathrm{~mL} \mathrm{~min}^{-1}\right)$. Then, the catalyst was purged in a pure helium flow until a constant baseline level was attained. Desorption was carried out with the linear heating rate $\left(10 \mathrm{~K} \mathrm{~min}^{-1}\right)$ in a flow of pure helium $\left(20 \mathrm{~mL} \mathrm{~min}^{-1}\right)$. Calibration of the quadrupole mass spectrometer with commercial mixtures allowed to recalculate the detector signal into a desorption rate of $\mathrm{NH}_{3}$ and NO. Apart from standard TPD measurements, desorption experiments for the samples preadsorbed with both $\mathrm{NH}_{3}$ and $\mathrm{NO}$ were also done. The outgassed catalyst $(673 \mathrm{~K}, 1 \mathrm{~h}$, helium flow - $\left.20 \mathrm{~mL} \mathrm{~min}^{-1}\right)$ was saturated with 1 vol. \% NO diluted in $\mathrm{He}\left(20 \mathrm{~mL} \mathrm{~min}^{-1}\right)$ for about 30 minutes at $343 \mathrm{~K}$. Then, the sample was purged in a helium flow until a constant baseline level was attained. Subsequently, the catalyst was saturated with 1 vol. $\% \mathrm{NH}_{3}$ diluted in $\mathrm{He}\left(20 \mathrm{~mL} \mathrm{~min}^{-1}\right)$ for about 30 minutes at the same temperature. After purging the sample in a flow of pure helium, the TPD measurements were performed. Desorption was carried out with the linear heating rate of $10 \mathrm{~K} \mathrm{~min}^{-1}$ in a flow of pure helium $\left(20 \mathrm{~mL} \mathrm{~min}^{-1}\right)$. These experiments are referred as NO$\mathrm{NH}_{3}$-TPD. In the case of the reverse order of adsorbed gases (first- $\mathrm{NH}_{3}$, second-NO), the experiments are referred as $\mathrm{NH}_{3}$-NO-TPD.

\subsubsection{Temperature-programmed surface reaction}

In the first step of temperature-programmed surface reaction experiment ( $\left.\mathrm{NH}_{3}-\mathrm{TPSR}\right)$, outgassed zeolite sample $\left(673 \mathrm{~K}, 1 \mathrm{~h}\right.$, helium flow - $20 \mathrm{~mL} \mathrm{~min}^{-1}$ ) was exposed to ammonia 
according to the procedure applied in the $\mathrm{NH}_{3}$-TPD measurements. In the next step the reactor was purged in a flow of pure helium $\left(20 \mathrm{~mL} \mathrm{~min}^{-1}\right)$, and then the catalyst was heated up to about $773 \mathrm{~K}$ with the linear increase of temperature $\left(10 \mathrm{~K} \mathrm{~min}^{-1}\right)$ in a flow of 1 vol. \% NO diluted in He $\left(20 \mathrm{~mL} \mathrm{~min}{ }^{-1}\right)$. The emitted gases were analysed by a quadrupole mass spectrometer connected on-line with the reactor outlet.

The reactivity of NO molecules adsorbed on the zeolite samples was studied by temperature-programmed surface reaction measurements (NO-TPSR). Prior to the NO-TPSR experiments, the zeolite sample was outgassed $\left(673 \mathrm{~K}, 1 \mathrm{~h}\right.$, helium flow $\left.-20 \mathrm{~mL} \mathrm{~min}^{-1}\right)$ and then cooled down to $343 \mathrm{~K}$. In the next step the catalyst was saturated at $343 \mathrm{~K}$ for $30 \mathrm{~min}$ with a gas mixture containing 1 vol. \% of NO diluted in helium $\left(20 \mathrm{~mL} \mathrm{~min}^{-1}\right)$, and subsequently purged with pure helium until a constant base level was attained. Finally, the sample was heated up to about $773 \mathrm{~K}$ with a linear increase of temperature $\left(10 \mathrm{~K} \mathrm{~min}^{-1}\right)$ in a flow of 1 vol. $\% \mathrm{NH}_{3}$ diluted in $\mathrm{He}\left(20 \mathrm{~mL} \mathrm{~min}^{-1}\right)$. A quadrupole mass spectrometer was used for analysis of gases.

\subsubsection{Stop-flow TPD}

Prior to the stop-flow TPD experiments, the catalysts $(100 \mathrm{mg})$ were activated in a flow of pure helium at $823 \mathrm{~K}$ for $30 \mathrm{~min}$. Then the reactor temperature decreased to $623 \mathrm{~K}$ and flow of helium was changed for the reaction mixture consisting of 0.25 vol. $\% \mathrm{NO}, 0.25 \mathrm{vol} . \% \mathrm{NH}_{3}$ and 2.5 vol. $\% \mathrm{O}_{2}$ diluted in helium, which was used as a balancing gas at a total flow rate of $40 \mathrm{~mL}$ $\min ^{-1}$. The catalytic test was carried out at $623 \mathrm{~K}$ for $1 \mathrm{~h}$. Subsequently, a flow of reacting mixture was exchanged for pure helium. The catalyst was purged in a helium flow until a constant baseline level was attained. Afterwards, in order to identify species adsorbed on the catalyst surface under reaction conditions, the TPD run was carried out with a linear heating rate of $10 \mathrm{~K} \mathrm{~min}^{-1}$ in a flow of pure helium $\left(20 \mathrm{~mL} \mathrm{~min}^{-1}\right)$ to about $823 \mathrm{~K}$. A quadrupole mass spectrometer was used for analysis of gases.

\subsubsection{FT-IR studies of the samples pre-adsorbed with reaction substrates}

The interaction of $\mathrm{NH}_{3}$ or $\mathrm{NO}$ with the surface of the catalysts as well as their reactivity was studied by FT-IR spectroscopy. The zeolite samples in the form of self-supported wafers were placed in the home-made quartz cell closed with $\mathrm{CaF}_{2}$ windows, transparent for the infra- 
red light. Cell was connected to the vacuum line and at the same time allowed for the adsorption of the gases in static condition. Wafers could be heated both during activation and adsorption. For the present measurement wafers were activated under vacuum at $723 \mathrm{~K}$ and FTIR spectra were recorded at $373 \mathrm{~K}$ with Bruker Tensor 27 spectrometer, equipped with an MCT detector. The course of typical experiment was as follow: $\mathrm{NH}_{3}$ or $\mathrm{NO}$ (purified before adsorption by freezeand-thaw) was adsorbed on the activated sample at $373 \mathrm{~K}$ and IR spectra were taken after consecutive desorption for 20 minutes at 373,473 and $573 \mathrm{~K}$ (all spectra recorded at $373 \mathrm{~K}$ ). Additional FTIR experiments in which NO was adsorbed on the samples with pre-adsorbed $\mathrm{NH}_{3}$ and $\mathrm{NH}_{3}$ was adsorbed on the samples with pre-adsorbed NO were also done. The samples with both $\mathrm{NH}_{3}$ and $\mathrm{NO}$ adsorbed were also evacuated at 373, 473 and $573 \mathrm{~K}$ and kept at each temperature for 20 minutes under vacuum before recording the spectrum at $373 \mathrm{~K}$.

\section{Results and discussion}

The most important physicochemical properties of the samples are presented in Table 1. As it was reported in a previous papers [6-9], all materials are characterized by high BET surface area of $642-790 \mathrm{~m}^{2} \mathrm{~g}^{-1}$ and micropore volume of $0.21-0.24 \mathrm{~cm}^{3} \mathrm{~g}^{-1}$, which are typical of the BEA structure and indicate that textural properties of BEA zeolite are preserved upon dealumination and introduction of cobalt into the zeolite structure by different methods. XRD patterns of all the samples are typical of BEA zeolite. For the Co-containing catalysts, dealumination of zeolite BEA by nitric acid does not affect its crystallinity (Fig. 1). Cobalt introduction does not lead to the appearance of XRD peaks characteristic of cobalt oxides (Fig. 1). The significant increase of $d_{302}$ spacing observed for the Co(PS)SiBEA sample upon incorporation of cobalt into SiBEA, from $3.887 \AA\left(2 \theta=22.86^{\circ}\right)$ for SiBEA to $3.898 \AA(2 \theta=$ $22.79^{\circ}$ ) for $\mathrm{Co}(\mathrm{PS}) \mathrm{SiBEA}$, indicates expansion of the zeolite matrix and introduction of cobalt into the framework positions of BEA zeolite (Fig. 1) [9]. Introduction of cobalt into HAlBEA zeolite by conventional wet impregnation and ion exchange methods leads to smaller increase in the $d_{302}$ spacing than that observed for introduction of cobalt into SiBEA support (Fig. 1), from $3.940 \AA\left(2 \theta=22.58^{\circ}\right)($ HAlBEA $)$ to $3.941 \AA\left(2 \theta=22.55^{\circ}\right)$ (Co(IMP)AlBEA and Co(IE)AlBEA) suggesting that only limited amount of cobalt may be successfully incorporated into the framework of HAlBEA zeolite by these methods [9] and as a result, the extraframework cobalt species should dominate over the framework ones. 
In all as obtained catalysts cobalt is present mainly as pseudo-tetrahedral $\mathrm{Co}(\mathrm{II})$, however it should be noted that in Co(IMP)AlBEA and Co(IE)AlBEA samples obtained by wet impregnation and ion exchange methods, also some amounts of extra-framework $\mathrm{Co}$ (II) in octahedral coordination are present (Fig. 2), as evidenced by the combined use of DR UV-vis and XPS methods, reported earlier [9]. The Co(IMP)AlBEA and Co(IE)AlBEA samples have a significantly higher concentration of the acidic sites than $\mathrm{Co}(\mathrm{PS}) \mathrm{SiBEA}$, as evidenced by FT-IR of adsorbed CO and TPD of ammonia. The differences in acidity of the catalysts are related to the presence of $\mathrm{Al}$ and Co species in the zeolite structure, which can act as Brønsted or Lewis acidic sites and influence catalytic properties of the obtained samples [9].

The as obtained Co-containing zeolites were studied as catalysts for the selective reduction of NO with ammonia $\left(\mathrm{DeNO}_{\mathrm{x}}, \mathrm{SCR}\right)$. The results of these studies are presented in Fig 3. The fully dealuminated BEA (SiBEA) shows a very low activity and NO conversion, which does not exceed $7 \%$ in the studied temperature range. The NO conversion substantially increases after incorporation of cobalt in the framework of SiBEA as shown for Co(PS)SiBEA (Fig. 3). For this sample, the reaction starts already at $423 \mathrm{~K}$ (Fig. 3) and the NO conversion reaches $90 \%$ with the selectivity to $\mathrm{N}_{2}$ above $90 \%$ at temperature $673 \mathrm{~K}$. It suggests that well dispersed framework pseudo-tetrahedral $\mathrm{Co}$ (II) are responsible for high activity of the catalyst in the SCR of NO process. For HAlBEA, the reaction starts at about $673 \mathrm{~K}$ and the NO conversion increase to 35 $40 \%$ at $723 \mathrm{~K}$ (Fig. 3). An introduction of cobalt into the HAlBEA support significantly increases its catalytic activity. The NO conversion starts at $473 \mathrm{~K}$ and increases to about $100 \%$ at $623 \mathrm{~K}$ with selectivity to nitrogen above $95 \%$ in the presence of the Co(IMP)AlBEA catalyst (Fig. 3). It seems that high conversion of NO measured over the Co(IMP)AlBEA catalyst is related to the co-presence of well dispersed pseudo-tetrahedral and octahedral Co(II) species. Figure 3 shows also the results of activity tests in the $\mathrm{DeNO}_{\mathrm{x}}$ process for the catalyst prepared by ion exchange method. The NO conversion measured for Co(IE)AlBEA increases in the range of 423 - $673 \mathrm{~K}$ reaching about $100 \%$. At higher temperatures the side process of direct ammonia oxidation significantly decreased the effectiveness of the DeNO ${ }_{x}$ process (Fig. 3). The selectivity to nitrogen, measured for $\mathrm{Co}(\mathrm{IE}) \mathrm{AlBEA}$, is above $90 \%$ in the broad temperature range (473 $723 \mathrm{~K})$. The catalytic activities of all the Co-containing zeolite catalysts are high, however, it should be noted that the catalysts with both pseudo-tetrahedral and octahedral Co(II) are more active in the low-middle temperature range (423 - $653 \mathrm{~K})$, while the sample containing only 
framework pseudo-tetrahedral cobalt species (Co(PS)SiBEA), shows higher activity at elevated temperatures ( $\mathrm{T}>653 \mathrm{~K}$ ) (Fig. 3). Thus, it seems that because of different contribution and state of cobalt species, well dispersed framework pseudo-tetrahedral $\mathrm{Co}(\mathrm{II})$ for $\mathrm{Co}(\mathrm{PS}) \mathrm{SiBEA}$ and well dispersed octahedral $\mathrm{Co}$ (II) in cationic extra-framework positions for $\mathrm{Co}$ (IMP)AlBEA and Co(IE)AlBEA, the obtained catalysts are characterised by different catalytic activities in the temperature range of $423-723 \mathrm{~K}$. It should be noted that commercial catalysts for this process, based on the $\mathrm{V}_{2} \mathrm{O}_{5}-\mathrm{TiO}_{2}$ oxide system, operate in a significantly narrower temperature range of 523-673 K. Therefore, these preliminary results obtained in our studies, are very promising. Earlier, Iwasaki et al. [50] studied catalytic performance of Fe/ZSM-5 prepared by various methods (IMP, IE, CVD) and shown that the iron-containing ZSM- 5 catalysts prepared by CVD method, demonstrate high activity in SCR-NO ( $100 \%$ NO conversion at about $573 \mathrm{~K})$. The similar results were reported by Delahay et al. [5]. Moreover, the results of the catalytic tests in SCR NO provided by Metkar et al., [16,51] and other authors [52-54] are characterized by a very similar performance of the dual-layer and dual-brick Fe/Cu-zeolite catalysts. However, it should be noted that the reaction conditions are different in both cases. Moreover, nitrogen oxide conversions measured for Co(IMP)AlBEA ( 100\% NO conversion at $623 \mathrm{~K}$ ) and Co(IE)AlBEA ( 90\% NO conversion at $623 \mathrm{~K}$ ), proves their high catalytic activity in SCR-NO with ammonia. Therefore, not only CVD but also IE or IMP methods result in well-defined catalysts, containing well dispersed $\mathrm{Co}$ (II) in pseudo-tetrahedral and octahedral coordination. It suggests that such Co(II) sites play major role in the SCR-NO reaction. The Co(IMP)AlBEA and Co(IE)AlBEA samples achieve high NO conversions over a broader temperature range and seems to be a strong alternative to the high-performance catalysts reported earlier [52-54]. Analysis of the catalytic results of $\mathrm{Co}$ (IMP)AlBEA and $\mathrm{Co}$ (IE)AlBEA in SCR-NO with $\mathrm{NH}_{3}$ (Fig. 3), have shown that ion exchange as well as wet impregnation procedure allow to obtain the high-performance catalysts. The aim of the presented below studies is to obtain more insight into the mechanism of the DeNO ${ }_{x}$ process over cobalt modified BEA zeolite.

\section{1. $\mathrm{NH}_{3}-\mathrm{TPD}$}

The $\mathrm{NH}_{3}$-TPD patterns of the zeolite samples are shown in Fig. 4. Apart from ammonia no other gas was emitted during the TPD runs. The ammonia desorption profile obtained for SiBEA zeolite is represented by a symmetric maximum at about $402 \mathrm{~K}$. The SiBEA sample is 
characterized by low acidity, represented by a relatively low concentration of adsorbed ammonia $\left(0.099 \mu \mathrm{mol} \mathrm{m} \mathrm{m}^{-2}\right)$. An introduction of cobalt into SiBEA by two-step postsynthesis method results in an increase of acidic sites concentration from $0.099 \mu \mathrm{mol} \mathrm{m}{ }^{-2}$ (for SiBEA) to $0.135 \mu \mathrm{mol} \mathrm{m}^{-2}$ (for $\mathrm{Co}(\mathrm{PS}) \mathrm{SiBEA}$ ). Therefore, it seems that cobalt ions incorporated into the zeolite support are responsible for the formation of additional centres for ammonia adsorption [55-62]. Moreover, incorporation of Co ions into the SiBEA support shifts TPD peaks to higher temperatures (Fig. 4), that suggests a slight increase in the strength of acidic sites in Co(PS)SiBEA [55]. For the samples prepared by wet impregnation and ion exchange methods, the TPD patterns can be divided into two ranges: 430 - $500 \mathrm{~K}$ and 500 - $625 \mathrm{~K}$ (Fig. 4). It should be noted that introduction of cobalt into the HAlBEA support results in decrease of acidic sites concentration by more than a half, from $1.882 \mu \mathrm{mol} \mathrm{m}{ }^{-2}$ (HAlBEA) to $0.834 \mu \mathrm{mol} \mathrm{m}{ }^{-2}$ (Co(IMP)AlBEA). An introduction of Co by ion exchange method into the HAlBEA support is also accompanied by a decrease in adsorbed ammonia concentration from $1.882 \mu \mathrm{mol} \mathrm{m} \mathrm{m}^{-2}$ (HAlBEA) to 1.519 $\mu \mathrm{mol} \mathrm{m}{ }^{-2}$ (Co(IE)AlBEA).

\subsection{NO-TPD}

The NO desorption profiles obtained for the HAlBEA, Co(PS)SiBEA, Co(IMP)AlBEA and Co(IE)AlBEA samples are shown in Fig. 5. First of all, it should be noted that the estimated content of nitrogen oxide adsorbed on HAlBEA, Co(PS)SiBEA, Co(IMP)AlBEA and $\mathrm{Co}(\mathrm{IE}) \mathrm{AlBEA}$ is significantly lower in comparison to chemisorbed ammonia, and is equal to $0.011,0.002,0.005$ and $0.008 \mu \mathrm{mol} \mathrm{m} \mathrm{m}^{-2}$, respectively. The NO-TPD profile of nitrogen oxide evolution from HAlBEA zeolite contains two desorption peaks at 396 and $558 \mathrm{~K}$. The NO desorption from the $\mathrm{Co}(\mathrm{PS}) \mathrm{SiBEA}$ sample occurs in the temperature range of $353-573 \mathrm{~K}$ and consists of one maximum at $463 \mathrm{~K}$ (Fig. 5), thus NO molecules are relatively weakly bound to the catalyst surface. The NO desorption from the Co(IMP)AlBEA proceeds in two stages (Fig. 5). The weakly chemisorbed NO molecules are desorbed in the range of 353 - $423 \mathrm{~K}$, while nitrogen oxide strongly bounded to the catalyst surface is released in the region of 423 - $593 \mathrm{~K}$ (Fig. 5). The NO-TPD desorption profile of the Co(IE)AlBEA sample consists of two maxima at 390 and $558 \mathrm{~K}$. It should be noted that desorption of NO from Co(IMP)AlBEA and Co(IE)AlBEA (containing both cobalt and aluminium) proceeds in two steps, indicating that NO forms species bounded to the surface with different strength and suggests that NO adsorbs at two different types 
of active sites. Since the peak at $558 \mathrm{~K}$ is also observed for HAlBEA, one can conclude that NO is probably bonded to aluminium sites with higher strength [63,64]. On the other hand for $\mathrm{Co}(\mathrm{PS}) \mathrm{SiBEA}$ (containing only cobalt species), only one NO desorption peak is found. Thus, it could be suggested that cobalt is responsible for the formation of weaker sites, which can be identified as pseudo-tetrahedral Co(II) framework sites [63,64].

\subsection{FT-IR of $\mathrm{NH}_{3}$ or NO adsorbed on Co(PS)SiBEA, Co(IMP)AlBEA and Co(IE)AlBEA}

In order to identify the nature of the surface species, the FT-IR spectra were recorded for the $\mathrm{Co}(\mathrm{PS}) \mathrm{SiBEA}, \mathrm{Co}(\mathrm{IMP}) \mathrm{AlBEA}$ and $\mathrm{Co}(\mathrm{IE}) \mathrm{AlBEA}$ catalysts on which $\mathrm{NH}_{3}$ or $\mathrm{NO}$ were adsorbed.

Fig. 6 shows the spectra recorded for the samples after NO adsorption and subsequent desorption at different temperatures (373, 473 and $573 \mathrm{~K}$ ). The FT-IR spectra recorded for Co(PS)SiBEA exhibit characteristic bands at 1875 and $1795 \mathrm{~cm}^{-1}$ (Fig. 6). These bands are due to nitrosyl complexes on cobalt cations [64-68]. In agreement with literature data [64-68], the bands at 1875 and $1795 \mathrm{~cm}^{-1}$ can be assigned to $\mathrm{Co}(\mathrm{II})-(\mathrm{NO})_{2}$ type dinitrosyls. The weak band at 1620 $\mathrm{cm}^{-1}$ present in the FT-IR spectrum for Co(PS)SiBEA (Fig. 6), indicates the presence of small amount of bridged $\mathrm{NO}\left(\mathrm{NO}_{2}\right)$ species [69]. FT-IR spectra recorded for the Co(IMP)AlBEA and Co(IE)AlBEA samples, exhibit bands at 1895, 1815 and $1620 \mathrm{~cm}^{-1}$, which can be assigned to Co(II)-(NO) 2 type dinitrosyls $\left(1895,1815 \mathrm{~cm}^{-1}\right)$ and bridged NO species $\left(1620 \mathrm{~cm}^{-1}\right)$ [66-69], respectively. For Co(IMP)AlBEA and Co(IE)AlBEA, additional IR band at $1930 \mathrm{~cm}^{-1}$ is observed (Fig. 6), which can be attributed to linear $\mathrm{Co}^{\mathrm{n}+}-\mathrm{NO}$ mononitrosyls [67]. In this case the possible oxidation state of cobalt ions is $3+$ since, as a rule, $\mathrm{Co}(\mathrm{II})-\mathrm{NO}$ compounds absorb at lower frequencies than Co(III)-NO (Fig. 6) [67]. The Co(III) species are formed as a result of NO adsorption, by in situ oxidation of Co(II) species, since their presence was not confirmed by UVVis and XPS studies for the samples not contacted with NO. It should also be mentioned that no band was observed at the region of $\mathrm{NO}^{+}$vibration. Obviously, since no $\mathrm{NO}^{+}$was observed, $\mathrm{NO}$ adsorption did not disturb the vibration of the $\mathrm{Si}-\mathrm{OH}-\mathrm{Al}$ groups.

As shown in Fig. 6, after $\mathrm{NH}_{3}$ adsorption FT-IR spectra for the Co(IMP)AlBEA and Co(IE)AlBEA samples, contain bands at 1455, 1620 and $1690 \mathrm{~cm}^{-1}$. The bands observed at 1455 and $1690 \mathrm{~cm}^{-1}$ can be attributed to $\mathrm{NH}_{4}{ }^{+}$species formed by the reaction of $\mathrm{NH}_{3}$ with Brønsted acidic sites (symmetric and antisymmetric N-H bending modes), while band at $1620 \mathrm{~cm}^{-1}$, proves 
the presence of Lewis acidity due to the formation of coordinatively bonded $\mathrm{NH}_{3}$ species [17,18,70-72] (Fig. 6). FT-IR spectrum of $\mathrm{Co}$ (PS)SiBEA after $\mathrm{NH}_{3}$ adsorption contains only one band at $1620 \mathrm{~cm}^{-1}$. It suggests that, in the $\mathrm{Co}(\mathrm{PS}) \mathrm{SiBEA}$ sample only Lewis acid sites originating from the presence of the framework cobalt species are present [17,18,70-72]. It should be noted that ammonia is much stronger bonded to the zeolite surface than nitric oxide because the bands related to ammonia bonded to Brønsted and Lewis acidic sites are still present in the FT-IR spectra of the catalysts evacuated at $573 \mathrm{~K}$ (Fig. 6).

\section{4. $\mathrm{NO}-\mathrm{NH}_{3}-\mathrm{TPD}, \mathrm{NH}_{3}-\mathrm{NO}-\mathrm{TPD}$ and FT-IR with $\mathrm{NO}+\mathrm{NH}_{3}$ or $\mathrm{NH}_{3}+\mathrm{NO}$}

Fig. 7 shows the results of $\mathrm{NO}-\mathrm{NH}_{3}-\mathrm{TPD}$ measurements (first adsorption of $\mathrm{NO}$ and then $\mathrm{NH}_{3}$ ) obtained for the Co(PS)SiBEA, Co(IMP)AlBEA and Co(IE)AlBEA catalysts. For all the studied samples, ammonia desorption patterns are similar to that measured in $\mathrm{NH}_{3}$-TPD (Fig. 4). It should be noted that apart from $\mathrm{NH}_{3}$ and $\mathrm{NO}$ desorption, also evolution of $\mathrm{N}_{2}$ and $\mathrm{H}_{2} \mathrm{O}$, which are the products of the SCR reaction, is detected in the range of 373 - $593 \mathrm{~K}$. The evolution of water vapour, which is spread to higher temperatures, suggests that $\mathrm{H}_{2} \mathrm{O}$ molecules do not desorb directly to gas phase but are bounded to the catalyst surface [70]. It should be noted that not all ammonia and nitrogen oxide molecules adsorbed on the studied catalysts are properly activated to be converted to $\mathrm{DeNO}_{\mathrm{x}}$ products and desorb in unchanged forms. For all the studied samples, the main peak of ammonia desorption, located at about $395-442 \mathrm{~K}$, is related to $\mathrm{NH}_{3}$ adsorbed on Lewis acidic sites, whereas the shoulder peak at $625 \mathrm{~K}$ can be assigned to $\mathrm{NH}_{3}$ adsorbed on Brønsted acidic centres, this is confirmed by the FT-IR studies (Fig. 9) because the maximum at $1620 \mathrm{~cm}^{-1}$ of coordinatively bonded $\mathrm{NH}_{3}$ disappears at lower desorption temperatures than the maximum at $1450 \mathrm{~cm}^{-1}$, characteristic of $\mathrm{NH}_{4}{ }^{+}$cations [58-60]. Nitrogen oxide molecules desorb mainly from framework cobalt sites at 350 - $600 \mathrm{~K}[63,64]$. For all the catalysts studied, the maxima of ammonia desorption fall at lower temperatures for zeolites with pre-adsorbed NO in comparison to $\mathrm{NH}_{3}$-TPD profiles for pure supports (Fig. 4). It may suggest that ammonia and nitrogen oxide adsorb on the same adsorption sites and NO, which is adsorbed as first, occupied part of stronger acidic sites and is not removed from these sites during subsequent ammonia adsorption. This is also confirmed by the fact that the intensity of the $\mathrm{NH}_{4}{ }^{+}$band (Fig. 9) is not influenced by the presence of the pre-adsorbed NO while the intensity of $1620 \mathrm{~cm}^{-1}$ band is reduced (the case of $\mathrm{Co}(\mathrm{IE}) \mathrm{AlBEA}$ ). Interestingly, in the case of $\mathrm{NH}_{3}$ adsorption right after $\mathrm{NO}$ 
adsorption, the band at $1930 \mathrm{~cm}^{-1}$ characteristic of $\mathrm{Co}(\mathrm{III})-\mathrm{NO}$ adducts is absent in this zeolite and the intensities of all dinitrosyls band is increased. This means that in the presence of $\mathrm{NH}_{3}$ the oxidation of cobalt sites by NO is reduced and that in fact the presence of ammonia influences the properties of the redox sites in the catalyst prepared by this method. The strength of NO and $\mathrm{NH}_{3}$ bonding in this zeolite is similar.

For $\mathrm{Co}(\mathrm{IMP}) \mathrm{AlBEA}$ adsorption of $\mathrm{NH}_{3}$ causes instantaneous $\mathrm{NO}$ desorption suggesting that ammonia is adsorbed at the same adsorption sites as NO and the former is bonded much stronger. $\mathrm{Co}(\mathrm{PS}) \mathrm{SiBEA}$ shows the reverse behaviour. In this case the presence of $\mathrm{NO}$ predominantly blocks the adsorption sites for ammonia. As evidenced by very low intensity of the band at $1620 \mathrm{~cm}^{-1}$ assigned to coordinatively bonded ammonia for this sample in comparison with Co(IMP)AlBEA and Co(IE)AlBEA samples. The band at $1620 \mathrm{~cm}^{-1}$ may originate both from $\mathrm{NO}$ and $\mathrm{NH}_{3}$ adsorption, but since the $\mathrm{N}-\mathrm{H}$ stretching maxima are present in the region 3400 to $3200 \mathrm{~cm}^{-1}$, this suggest that the band $1620 \mathrm{~cm}^{-1}$ may be assigned only to coordinatively bonded ammonia. Thus, for Co(PS)SiBEA ammonia is bonded on different adsorption sites than $\mathrm{NO}$ and the presence of adsorbed $\mathrm{NH}_{3}$ is only slightly influencing the redox properties of framework cobalt sites.

Fig. 8 shows the results of $\mathrm{NH}_{3}-\mathrm{NO}-\mathrm{TPD}$ (first adsorption of $\mathrm{NH}_{3}$ and then $\mathrm{NO}$ ) measurements for Co(PS)SiBEA, Co(IMP)AlBEA and Co(IE)AlBEA. For Co(PS)SiBEA, the nitrogen and water vapour are formed in the temperature range from 373 to $553 \mathrm{~K}$ (Fig. 8), while the evolution of these products in case of Co(IMP)AlBEA and Co(IE)AlBEA is spread in the range of 393 - $653 \mathrm{~K}$ (Fig. 8). The profiles of nitrogen and water vapour evolution obtained for Co(IMP)AlBEA and Co(IE)AlBEA, contain two maxima, which proves that part of water is emitted directly to the gas phase (maxima at 433 and $441 \mathrm{~K}$ ), while another part of $\mathrm{H}_{2} \mathrm{O}$ molecules is bounded to the catalyst surface (maxima at 502 and 512 K) (Fig. 8) (e.g. in the form of -OH groups), and is removed from the catalysts at higher temperatures [14]. It should be underlined that the quantity of chemisorbed $\mathrm{NO}$ estimated in $\mathrm{NH}_{3}-\mathrm{NO}-\mathrm{TPD}$ is lower than that assessed in $\mathrm{NO}-\mathrm{NH}_{3}-\mathrm{TPD}$, which suggests that $\mathrm{NH}_{3}$ molecules (adsorbed prior to NO adsorption) partially block active sites for NO adsorption and proves the hypothesis that ammonia and nitrogen oxide molecules compete for the same adsorption sites [17,48,49].

The FT-IR spectra recorded for the samples pre-adsorbed with $\mathrm{NH}_{3}$ before $\mathrm{NO}$ adsorption are shown in Fig. 10. In case of $\mathrm{Co}(\mathrm{IMP}) \mathrm{AlBEA}$ and $\mathrm{Co}(\mathrm{IE}) \mathrm{AlBEA}$, after $\mathrm{NH}_{3}$ adsorption the 
presence of the bands at 1455, 1690 and $1620 \mathrm{~cm}^{-1}$ proves the presence of Brønsted and Lewis acidic sites, respectively [18,57,70-72]. The band at $1805 \mathrm{~cm}^{-1}$, observed in FT-IR spectra for Co(IMP)AlBEA and Co(IE)AlBEA after NO adsorption, can be assigned to Co(II)-(NO) 2 type dinitrosyls [66-69], the symmetric band with much lower absorption coefficient is almost invisible. The Co(PS)SiBEA sample contains Lewis acidic sites (Co(II) species) characterized by the $\mathrm{NH}_{3}$ adsorption band at $1620 \mathrm{~cm}^{-1}[17,18,70,71]$ and with $\mathrm{NO}$ adsorption bands at 1790 and $1875 \mathrm{~cm}^{-1}$ [66-69] (Fig. 10).

Analysis of the obtained spectra recorded for the samples, shows that NO adsorption on the samples with pre-adsorbed $\mathrm{NH}_{3}$ is very limited, and replacement of ammonia by $\mathrm{NO}$ on BEA zeolite is very difficult. Thus, the obtained results show that $\mathrm{NO}$ and $\mathrm{NH}_{3}$ molecules compete for the same adsorption sites, and ammonia is able to remove NO from the active centres $[13,15,17,48,49]$. The only exception are framework Co(II) sites in Co(PS)SiBEA, which adsorbs NO much stronger than ammonia. In fact, there is negligible amount of ammonia adsorbed in this zeolite, due to the absence of aluminium-based Brønsted and Lewis acid sites. Moreover, combined temperature-programmed studies and FT-IR with $\mathrm{NO}$ and/or $\mathrm{NH}_{3}$ adsorption of the reaction mechanism show that the $\mathrm{DeNO}_{\mathrm{x}}$ process performed in the presence of Co(IMP)AlBEA and $\mathrm{Co}(\mathrm{IE}) \mathrm{AlBEA}$ involves the reaction between chemisorbed ammonia and NO from gas phase (Eley-Riedel mechanism) [73,74]. In case of Co(PS)SiBEA a significant role of strongly adsorbed NO on framework cobalt species in the $\mathrm{DeNO}_{\mathrm{x}}$ mechanism cannot be excluded.

General conclusions from the FT-IR analysis may be summarized as follows. There are two type of cobalt centres present in the investigated zeolites: (i) Framework, pseudo-tetrahedral $\mathrm{Co}(\mathrm{II})$ species, the most abundant in Co(PS)SiBEA zeolite, in which cobalt occupies the position taken before by the framework Al atoms. Such centres are able to bond NO much stronger than $\mathrm{NH}_{3}$ and are not easily oxidized by NO (ii) Extra-framework, probably octahedral Co(II) species, the most abundant in $\mathrm{Co}(\mathrm{IE})$ AlBEA. They bond $\mathrm{NH}_{3}$ much strongly than $\mathrm{NO}$ (NO is instantaneously flushed by $\mathrm{NH}_{3}$ ). Presence of $\mathrm{NH}_{3}$ is influencing their redox properties, since they are easily oxidized to $\mathrm{Co}(\mathrm{III})$ in the absence of ammonia and oxidation is stopped in the $\mathrm{NH}_{3}$ presence.

Both types of centres are present in the Co(IMP)AlBEA and thus this zeolite behaviour is intermediate - some of the cobalt centres preferentially adsorb NO and some - ammonia. The presence of $\mathrm{NH}_{3}$ is influencing the properties of extraframework cobalt(II) only. 


\subsection{NO-TPSR}

The reactivity of pre-adsorbed nitrogen oxide was studied by temperature-programmed surface reaction (NO-TPSR) performed in a continuous flow of helium-diluted ammonia. Results obtained for all studied samples are shown in Fig. 11. It should be noted that significant amounts of ammonia are adsorbed on the catalyst surface just after a flow of $\mathrm{NH}_{3} / \mathrm{He}$ gas mixture was switched on $[60,70]$. In spite of pre-adsorbed NO, the samples adsorb ammonia from the gas phase up to about 353 - $393 \mathrm{~K}$ without NO desorption (Fig. 8), what suggests that $\mathrm{NH}_{3}$ molecules are firstly chemisorbed on sites non-occupied by NO molecules. At higher temperature (403 - 523 K), ammonia replaces weakly adsorbed NO from surface sites (Fig. 11) $[48,49,60]$. It should be noted that NO desorption patterns for all the catalysts are similar to that obtained in NO-TPD (Fig. 5) or NO-NH $3-\mathrm{TPD}$ (Fig. 7). For all the studied samples, the reaction between $\mathrm{NH}_{3}$ and $\mathrm{NO}$ adsorbed species occurred, forming $\mathrm{N}_{2}$ and $\mathrm{H}_{2} \mathrm{O}$. In case of $\mathrm{Co}(\mathrm{PS}) \mathrm{SiBEA}$, the evolution of $\mathrm{N}_{2}$ and $\mathrm{H}_{2} \mathrm{O}$ is detected in the temperature range of $353-523 \mathrm{~K}$ (Fig. 11), while in the presence of the Co(IMP)AlBEA and Co(IE)AlBEA samples, nitrogen and water vapour are realised in the temperature range of 393 - $653 \mathrm{~K}$ (Fig. 11), which indicates that surface nitrates are converted by ammonia into the $\mathrm{DeNO}_{\mathrm{x}}$ products [70]. It is worth noting that nitrous oxide production is not detected for the studied catalysts, which is consistent with the earlier studies on Fe-ZSM-5 [37].

\section{6. $\mathrm{NH}_{3}-\mathrm{TPSR}$}

The reactivity of $\mathrm{NH}_{3}$ pre-adsorbed on the catalyst surface was characterized by temperature-programmed surface reaction $\left(\mathrm{NH}_{3}\right.$-TPSR) performed in a continuous flow of helium-diluted NO. The $\mathrm{NH}_{3}$-TPSR profiles are shown in Fig. 12. The ammonia desorption patterns obtained for all the samples are spread in the range of 353 - $533 \mathrm{~K}$. It is shown in Fig. 12, that the reaction between $\mathrm{NO}$ and pre-adsorbed $\mathrm{NH}_{3}$ species occurred, producing $\mathrm{N}_{2}$ and $\mathrm{H}_{2} \mathrm{O}$ $[60,70]$. The $\mathrm{NH}_{3}$ desorption pattern obtained for $\mathrm{Co}(\mathrm{PS}) \mathrm{SiBEA}$ is spread in the range of 353 $453 \mathrm{~K}$ with maximum at $405 \mathrm{~K}$ (Fig. 12). The evolution of nitrogen in case of the Co(PS)SiBEA sample begins at temperature as low as $353 \mathrm{~K}$ (Fig. 12), while the emission of $\mathrm{H}_{2} \mathrm{O}$ molecules is detected in the range from 353 to $753 \mathrm{~K}$ with two maxima at 412 and $648 \mathrm{~K}$ (Fig. 12), respectively $[60,70]$. Similar TPSR patterns are recorded for the Co(IMP)AlBEA and Co(IE)AlBEA samples, however, maxima of nitrogen and water vapour evolution are found in 
different positions in relation to that found for the $\mathrm{Co}(\mathrm{PS}) \mathrm{SiBEA}$ sample (Fig. 12). In all $\mathrm{NH}_{3}$ TPSR experiments, evolution of $\mathrm{H}_{2} \mathrm{O}$ molecules occurs at higher temperature than emission of nitrogen, suggesting that $\mathrm{N}_{2}$ immediately desorbs from the catalyst surface, while water is bonded much strongly to the catalyst surface, and remains on the surface to higher temperature [60,70]. It is worth to notice that the rate of the nitrogen and water formation proceeds with an increase in reaction temperature until ammonia is completely removed from the catalyst surface $[60,70]$. Moreover, for all the studied catalysts, only the fraction of chemisorbed ammonia is converted into the DeNO ${ }_{x}$ products, while majority of $\mathrm{NH}_{3}$ desorbs from the zeolite surface. This fact suggests that only part of chemisorbed ammonia is activated properly to be converted into the DeNO $_{x}$ products [60].

\subsection{Stop flow-TPD}

In order to check what type of species is present on the catalyst surface under reaction conditions, stop flow-TPD experiments were performed for the studied samples. After isothermal catalytic test performed at $623 \mathrm{~K}$ for 1 hour, the catalyst sample was purged in a flow of helium and then TPD measurement in a flow of pure helium was done in order to identify species present on the catalyst surface. The results of this study are shown in Fig. 13. It should be underline that chemisorbed ammonia molecules are the main species present under reaction conditions in case of the studied catalysts. Ammonia desorption from Co(PS)SiBEA (sample without Al but containing Co species) occurs in the range of 643 - $673 \mathrm{~K}$, while for Co(IMP)AlBEA and Co(IE)AlBEA (containing both $\mathrm{Al}$ and Co species), only above $683 \mathrm{~K}$ (Fig. 13). These differences can be related to different acidity of cobalt and aluminium species. Evolution of nitrogen oxide for all the studied catalysts is detected in very similar ranges as desorption of ammonia from these samples, however amount of desorbing NO is significantly lower comparing to ammonia desorption $[13,15,17,48,49]$. In case of $\mathrm{Co}(\mathrm{PS}) \operatorname{SiBEA}$ chemisorbed ammonia and nitrogen oxide present low reactivity and therefore, only slight amount of nitrogen is formed during the experiment. Larger amounts of nitrogen is formed as results the reaction between $\mathrm{NH}_{3}$ and NO chemisorbed on the surface of Co(IMP)AlBEA and Co(IE)AlBEA. The results of the presented studies lead to the conclusion that the main reaction pathway proceeds by adsorption and activation of $\mathrm{NH}_{3}$ molecules on the zeolite catalysts surface $[13,15,17,48,49]$. It must be stressed that only part of adsorbed ammonia is properly activated for the DeNO $\mathrm{N}_{\mathrm{x}}$ process, while 
part of them are only spectators $[13,15,17]$. In case all studied samples only small amount of NO molecules, in comparison to ammonia, is adsorbed, possibly in the form of nitrates, on the catalyst surface under reaction conditions. Thus, probably the main reaction proceeds between chemisorbed ammonia and NO from gas phases (or loosely bounded to the catalyst surface) $[13,15,17]$.

\section{Conclusions}

The modification of the BEA supports with cobalt results in their catalytic activation in the DeNO $_{x}$ process. It was shown that cobalt introduced in the zeolitic supports effectively activates chemisorbed $\mathrm{NH}_{3}$ molecules for reaction with $\mathrm{NO}$.

The highest reactivity of ammonia in the SCR-NO reaction, with the high selectivity towards nitrogen, was found for the Co(IE)AlBEA catalyst, prepared by ion exchange method.

Total conversion of chemisorbed $\mathrm{NH}_{3}$ is not observed for any zeolite catalyst. Probably, not all ammonia and nitrogen oxide molecules adsorbed on the studied catalysts are properly activated to be converted to DeNOx products and desorb in the unchanged forms. The surface concentration of chemisorbed $\mathrm{NO}$ is lower in comparison to chemisorbed $\mathrm{NH}_{3}$ in case of all the samples studied.

The results of temperature-programmed studies and FT-IR with $\mathrm{NO}$ and/or $\mathrm{NH}_{3}$ adsorption for the Co-containing samples, show that during the SCR reaction, ammonia and nitrogen oxide adsorb on the same adsorption sites. In general, ammonia is stronger bound to the catalyst surface in comparison with $\mathrm{NO}$ and is able to remove nitrogen oxide molecules from the adsorption sites. An exception is NO adsorbed on stronger Lewis acid sites, probably framework Co(II) species, which was not removed from these sites during subsequent ammonia adsorption on the $\mathrm{Co}(\mathrm{PS}) \mathrm{SiBEA}$ sample. Analogously, $\mathrm{NH}_{3}$ molecules adsorbed prior to $\mathrm{NO}$ adsorption probably block active sites for NO adsorption on Co(IMP)AlBEA. In case of Co(IE)AlBEA, it is partially blocking of active sites by ammonia, while for Co(PS)SiBEA zeolite, this effect does not appear. It proves the hypothesis that ammonia and nitrogen oxide molecules compete for the same adsorption sites.

The results of FT-IR studies for the catalysts pre-adsorbed with both $\mathrm{NO}$ and $\mathrm{NH}_{3}$, clearly show that nitrogen oxide is desorbed from Co(IMP)AlBEA immediately upon contact with 
ammonia, while in case of $\mathrm{Co}(\mathrm{PS}) \mathrm{SiBEA}$ and $\mathrm{Co}(\mathrm{IE}) \mathrm{AlBEA}$, ammonia does not displace completely nitrogen oxide.

Comparison of the results of catalytic tests and results of the reaction mechanism studies leads to the conclusion that extra-framework cobalt species are more catalytically active in comparison to $\mathrm{Co}$ (II) cations incorporated to the BEA zeolite framework. In case of the extraframework cobalt species the reaction procced according to Eley-Riedel mechanism including reaction between chemisorbed ammonia and NO from gas phase. On the other hand, in case of the $\mathrm{Co}(\mathrm{PS}) \mathrm{SiBEA}$ catalyst an important role of $\mathrm{NO}$ adsorbed on $\mathrm{Co}$ (II) cations incorporated into the BEA zeolite framework in the mechanism of the DeNOx process cannot be excluded.

\section{Acknowledgement}

This research has received funding from the Marian Smoluchowski Kraków Research Consortium - a Leading National Research Centre KNOW supported by the Ministry of Science and Higher Education.

Part of the research was carried out with the equipment purchased thanks to the financial support of the European Regional Development Fund in the framework of the Polish Innovation Economy Operational Program (contract no. POIG.02.01.00-12-023/08).

The presented studies were performed in the frame of GDRI programme. 


\section{References}

[1] P. Forzatti, Appl. Catal. A 222 (2003) 221.

[2] C. Ciardelli, I. Nova, E. Tronconi, D. Chatterjee, B. Bandl-Konrad, M. Weibel, B. Krutzsch, Appl. Catal. B 70 (2007) 80.

[3] I. Nova, C. Ciardelli, E. Tronconi, D. Chatterjee, B. Bandl-Konrad,

Catal. Today 114 (2006) 3.

[4] H. Ohtsuka, Appl. Catal. B 33 (2001) 325.

[5] G. Delahay, D. Valade, A. Guzman-Vargas, B. Coq, Appl. Catal. B 55 (2005) 149.

[6] P. Boroń, L. Chmielarz, J. Gurgul, K. Łątka, T. Shishido, J-M. Krafft, S. Dzwigaj, Appl. Catal. B 138-139 (2013) 434.

[7] P. Boroń, L. Chmielarz, J. Gurgul, K. Łątka, B. Gil, J-M. Krafft, S. Dzwigaj,

Catal. Today 235 (2014) 210.

[8] P. Boroń, L. Chmielarz, J. Gurgul, K. Łątka, B. Gil, B. Marszałek, S. Dzwigaj,

Micropor. Mesopor. Mater. 203 (2015) 73.

[9] P. Boroń, L. Chmielarz, S. Casale, C. Calers, J-M. Krafft, S. Dzwigaj,

Catal. Today 258 (2015) 507.

[10] M.C. Kung, P.W. Park, D.-W. Kim, H.H. Kung, J. Catal. 181 (1999) 1.

[11] P.W. Park, H.H. Kung, D.-W. Kim, M.C. Kung, J. Catal. 184 (1999) 440.

[12] A. Grossale, I. Nova, E. Tronconi, Catal. Today 136 (2008) 18.

[13] M. Ruggeri, A. Grossale, I. Nova, E. Tronconi, H. Jirglova, Z. Sobalik, Catal. Today 184 (2012) 107.

[14] S. Shrestha, M. Harold, K. Kamasamudram, A. Yezerets, Catal. Today 231 (2014) 105.

[15] K. Kamasamudram, N. Currier, X. Chen, A. Yezerets, Catal. Today 151 (2010) 212.

[16] P. Metkar, M. Harold, V. Balakotaiah, Appl. Catal. B 111-112 (2012) 67.

[17] D. Klukowski, P. Balle, B. Geiger, S. Wagloehner, S. Kureti, B. Kimmerle, A. Baiker,

J. Grunwaldt, Appl. Catal. B 93 (2009) 185.

[18] R. Long and R. Yang, J. Catal. 207 (2002) 224.

[19] A. Grossale, I. Nova, E. Tronconi, D. Chatterjee, M. Weibel, J. Catal. 256 (2008) 312.

[20] A. Grossale, I. Nova, E. Tronconi, J. Catal. 265 (2009) 141.

[21] T. Montanari, O. Marie, M. Daturi, G. Busca, Appl. Catal. B 71 (2007) 216.

[22] J. Zhang, Y. Liu, W. Fan, Y. He, R. Li, Fuel 86 (2007) 1577. 
[23] P. J. Smeets, Q. Meng, S. Corthals, H. Leeman, R.A. Schoonheydt, Appl. Catal. B 84 (2008) 505.

[24] T. J. Lee, I.S. Nam, S.W. Ham, Y.S. Baek, K.H. Shin, Appl. Catal. B 41 (2003) 115.

[25] J. H. Park, C.H. Park, I.S. Nam, Appl. Catal. A 277 (2004) 271.

[26] S. Capela, R. Catalao, M.F. Ribeiro, P.D. Costa, G.D. Mariadassou, F.R. Ribeiro,

C. Henriques, Catal. Today 137 (2008) 157.

[27] H. H. Chen, S.C. Shen, X. Chen, S. Kawi, Appl. Catal. B 50 (2004) 37.

[28] A. P. Ferreira, C. Henriques, M.F. Ribeiro, F.R. Ribeiro, Catal. Today 107-108 (2005) 181.

[29] T. Montanari, O. Marie, M. Daturi, G. Busca, Catal. Today 110 (2005) 339.

[30] F. Lonyi, J. Valyon, L. Gutierrez, M.A. Ulla, E.A. Lombardo, Appl. Catal. B 73 (2007) 1.

[31] H. Chen, Q. Sun, B. Wen, Y. Yeom, E. Weitz, W. Sachtler, Catal. Today 96 (2004) 1.

[32] C. Resini, T. Montanari, L. Nappi, G. Bagnasco, M. Turco, G. Busca, F. Bregani,

M. Notaro, G. Rocchini, J. Catal. 214 (2003) 179.

[33] C. Chupin, A.C. van Veen, M. Konduru, J. Despres, C. Mirodatos, J. Catal. 241 (2006) 103.

[34] L. J. Lobree, A.W. Aylor, J.A. Reimer, A.T. Bell, J. Catal. 169 (1997) 188.

[35] L. F. Liotta, G. Pataleo, A. Macaluso, G. Di Carlo, G. Deganello, Appl. Catal. A 245 (2003) 167.

[36] L. Chen, T. Horiuchi, T. Mori, Catal. Lett. 72 (2001) 71.

[37] A. Sarellas, D. Niakolas, K. Bourikas, J. Vakros, C. Kordulis,

J. Colloid Interface Sci. 295 (2006) 165.

[38] R. Burch, J.P. Breen, F.C. Meunier, Appl. Catal. B 39 (2002) 283.

[39] E. M. Sadovskaya, A.P. Suknev, L.G. Pinaeva, V.B. Goncharov, B.S. Balzhinimaev,

C. Chupin, J. Perez-Ramirez, C. Mirodatos, J. Catal. 225 (2004) 179.

[40] E. A. Lombardo, G.A. Sill, J.L. d'Itri, W.K. Hall, J. Catal. 173 (1998) 440.

[41] F. Witzel, G.A. Sill, W.K. Hall, J. Catal. 149 (1994) 229.

[42] A. D. Cowan, R. Dumpelmann, N.W. Cant, J. Catal. 151 (1995) 356.

[43] Q. Sun, Z. Gao, H. Chen, W. Sachtler J. Catal. 201 (2001) 89.

[44] J. Eng, C. Bartholomew, J. Catal. 171 (1997) 14.

[45] Y. Yeom, J. Henao, M. Li, W. Sachtler, E. Weitz, J. Catal. 231 (2005) 181.

[46] R. Long, R. Yang, J. Catal. 194 (2000) 80.

[47] L. Lobree, I. Hwang, J. Reimer, A. Bell, J. Catal. 186 (1999) 242. 
[48] E. Tronconi, L. Lietti, P. Forzatti, S. Malloggi, Chem. Eng. Sci. 51 (1996) 2965.

[49] L. Lietti, I. Nova, E. Tronconi, P. Forzatti, AIChE Journal 43 (1997) 2559.

[50] M. Iwasaki, K. Yamazaki, K. Banno, H. Shinjoh, J. Catal. 260 (2008) 205.

[51] P.S. Metkar, M.P. Harold, V. Balakotaiah, Chem. Eng. Sci. 87 (2013) 51.

[52] O. Krocher, M. Elsener, Ind. Eng. Chem. Res. 47 (2008) 8588.

[53] A. Obuchi, I. Kaneko, J. Uchisawa, A. Ohi, A. Ogata, G.R. Bamwenda, S. Kushiyama, Appl. Catal. B 19 (1998) 127.

[54] C.-S. Kang, Y.-J. You, K.-J. Kim, T.-H. Kim, S.-J. Ahn, K.-H. Chung, N.-C. Park,

S. Kimura, H.-G. Ahn, Catal. Today 111 (2006) 229.

[55] R. Beaumont, D. Barthomeuf, J. Catal. 26 (1972) 218.

[56] A. Camiloti, S. Jahn, N. Velasco, L. Moura, D. Cardoso, Appl. Catal. A 182 (1999) 107.

[57] K. Krishna, M. Makkee, Catal. Today 114 (2006) 23.

[58] S. Brandenberger, O. Kröcher, A. Wokaun, A. Tissler, R. Althoff, J. Catal. 268 (2009) 297.

[59] A. Ates, A. Reitzmann, G. Waters, Appl. Catal. B 119 (2012) 329.

[60] R. Long, R. Yang, J. Catal. 198 (2001) 20.

[61] J. Jansen, E. Creyghton, S. Njo, H. van Koningsveld, H. van Bekkum,

Catal. Today 38 (1997) 205.

[62] J. Newsam, M. Treacy, W. Koetsier, C. Gruyter, Proc. R. Soc. Lond. A 420 (1988) 375.

[63] Y. Chang, J. McCarty, J. Catal. 165 (1997) 1.

[64] V. Matyshak, A. Ilichev, A. Ukharsky, V. Korchak, J. Catal. 171 (1997) 245.

[65] B. Djonev, B. Tsyntsarski, D. Klissurski, K. Hadjiivanov,

J. Chem. Soc., Faraday Trans. 93 (1997) 4055.

[66] K. Hadjiivanov, B. Tsyntsarski, T. Nikolova, Phys. Chem. Chem. Phys. 1 (1999) 4521.

[67] K. Hadjiivanov, D. Panayotov, V. Avreyska, B. Tsyntsarski, D. Klissurski, T. Marinova, Surf. Interf. Anal. 34 (2002).

[68] K. Hadjiivanov, V. Avreyska, D. Klissurski, Ts. Marinova, Langmuir 18 (2002) 1619.

[69] T. Tabata, H. Ohtsuka, L.M.F. Sabatino, G. Bellussi,

Micropor. Mesopor. Mater. 21 ( 1998) 517.

[70] L. Chmielarz, P. Kuśtrowski, M. Zbroja, B. Gil-Knap, J. Datka, R. Dziembaj, Appl. Catal. B 53 (2004) 47.

[71] F. Liu, K. Asakura, H. He, Y. Liu, W. Shan, X. Shi, C. Zhang, Catal. Today 164 (2011) 520. 
[72] F. Liu, H. He, Catal. Today 153 (2010) 70.

[73] K. Hadjiivanov, Catal. Rev. 42 (2000) 71.

[74] G. Busca, L. Lietti, G. Ramis, F. Berti, Appl. Catal. B 18 (1998) 1. 
Figure captions

Figure 1. XRD patterns recorded at room temperature of HAlBEA, Co(PS)SiBEA, Co(IMP)AlBEA and Co(IE)AlBEA.

Figure 2. DR UV-vis spectra recorded at ambient atmosphere of Co(PS)SiBEA, Co(IMP)AlBEA and Co(IE)AlBEA.

Figure 3. $\mathrm{NO}$ conversion and $\mathrm{N}_{2}$ selectivity in SCR of $\mathrm{NO}$ with $\mathrm{NH}_{3}$ of SiBEA, HAlBEA, Co(PS)SiBEA, Co(IMP)AlBEA and Co(IE)AlBEA.

Figure 4. $\mathrm{NH}_{3}-\mathrm{TPD}$ profiles of SiBEA, HAlBEA, $\mathrm{Co}(\mathrm{PS}) \mathrm{SiBEA}, \mathrm{Co}(\mathrm{IMP}) \mathrm{AlBEA}$ and Co(IE)AlBEA.

Figure 5. NO-TPD of HAlBEA, Co(PS)SiBEA, Co(IMP)AlBEA and Co(IE)AlBEA.

Figure 6. FTIR spectra of $\mathrm{NO}$ (first line) and $\mathrm{NH}_{3}$ (second line) adsorbed on $\mathrm{Co}$ (IE)AlBEA, Co(IMP)AlBEA and Co(PS)SiBEA zeolites activated under vacuum at $723 \mathrm{~K}$. All spectra at 373 $\mathrm{K}$, normalized to $10 \mathrm{mg}$ of catalyst.

Figure 7. The results of NO-NH 3 -TPD experiments obtained for $\mathrm{Co}(\mathrm{PS}) \mathrm{SiBEA}, \mathrm{Co}(\mathrm{IMP}) \mathrm{AlBEA}$ and Co(IE)AlBEA.

Figure 8. The results of $\mathrm{NH}_{3}-\mathrm{NO}-\mathrm{TPD}$ experiments obtained for $\mathrm{Co}(\mathrm{PS}) \mathrm{SiBEA}, \mathrm{Co}(\mathrm{IMP}) \mathrm{AlBEA}$ and $\mathrm{Co}(\mathrm{IE}) \mathrm{AlBEA}$.

Figure 9. FTIR spectra of $\mathrm{NH}_{3}$ adsorption on $\mathrm{Co}(\mathrm{IE}) \mathrm{AlBEA}, \mathrm{Co}(\mathrm{IMP}) \mathrm{AlBEA}$ and $\mathrm{Co}(\mathrm{PS}) \mathrm{SiBEA}$ zeolites with pre-adsorbed NO. All spectra at $373 \mathrm{~K}$, normalized to $10 \mathrm{mg}$ of catalyst.

Figure 10. FTIR spectra of NO adsorption on Co(IE)AlBEA, Co(IMP)AlBEA and Co(PS)SiBEA zeolites with pre-adsorbed $\mathrm{NH}_{3}$. All spectra at $373 \mathrm{~K}$, normalized to $10 \mathrm{mg}$ of catalyst.

Figure 11. The results of NO-TPSR measurements for Co(PS)SiBEA, Co(IMP)AlBEA and Co(IE)AlBEA.

Figure 12. The results of $\mathrm{NH}_{3}$-TPSR measurements for $\mathrm{Co}(\mathrm{PS}) \mathrm{SiBEA}, \mathrm{Co}(\mathrm{IMP}) \mathrm{AlBEA}$ and Co(IE)AlBEA.

Figure 13. The results of stop-flow TPD experiments for $\mathrm{Co}(\mathrm{PS}) \mathrm{SiBEA}, \mathrm{Co}(\mathrm{IMP}) \mathrm{AlBEA}$ and Co(IE)AlBEA. 


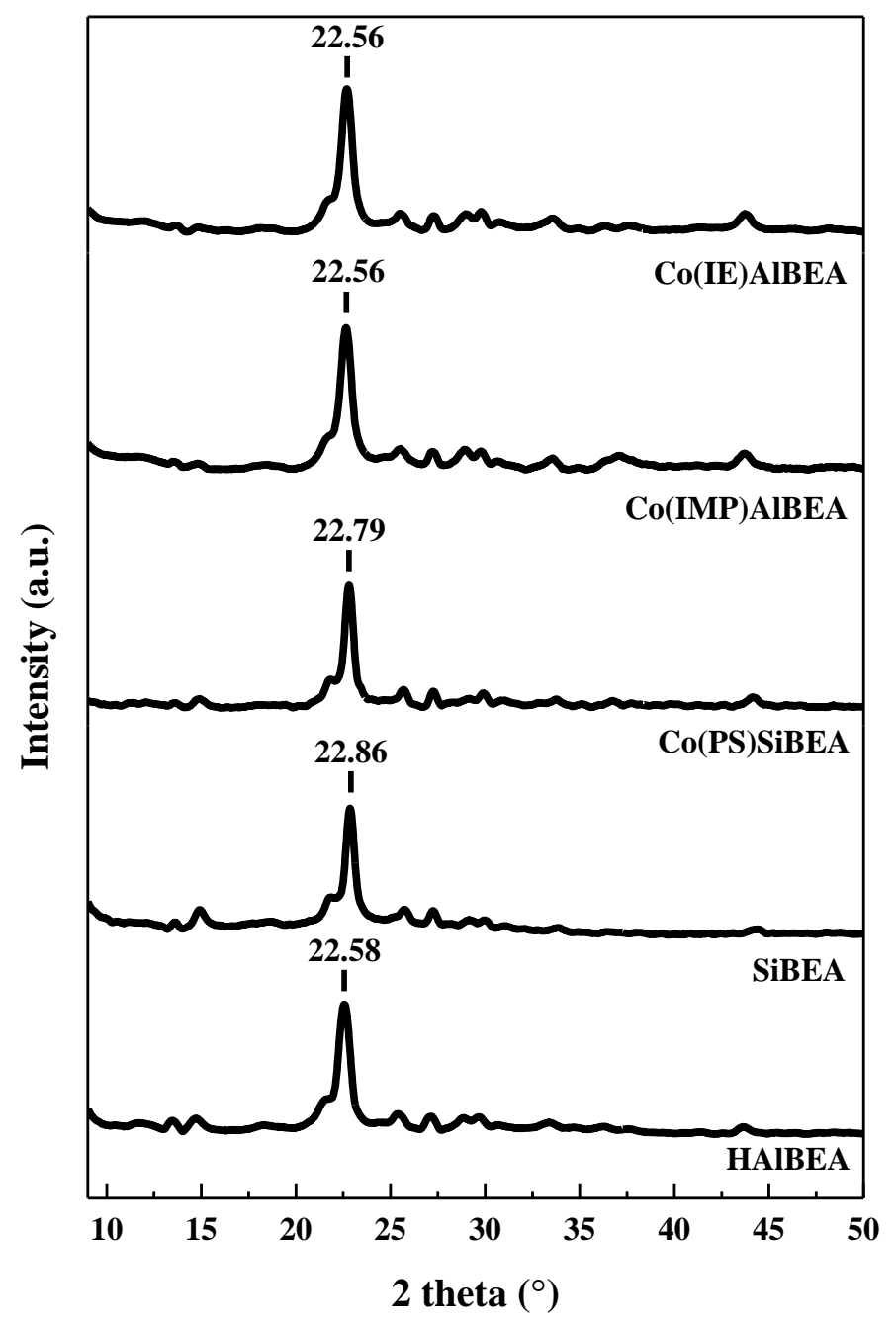

Fig. 1 


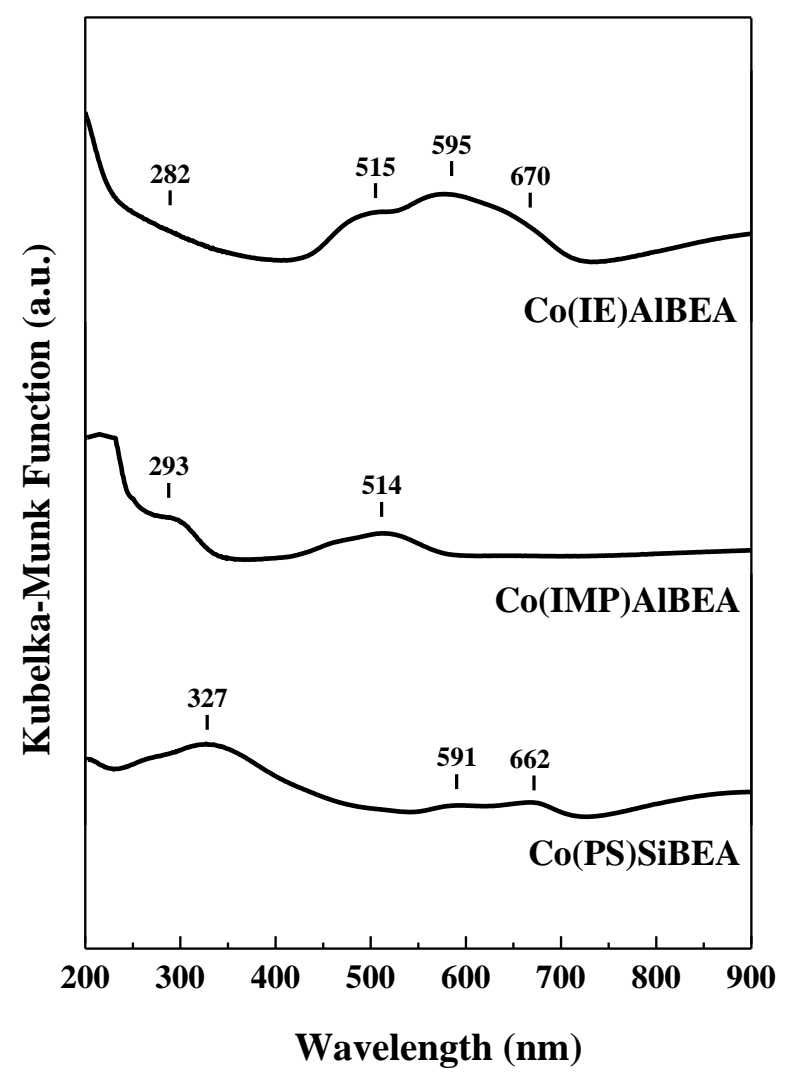

Fig. 2 


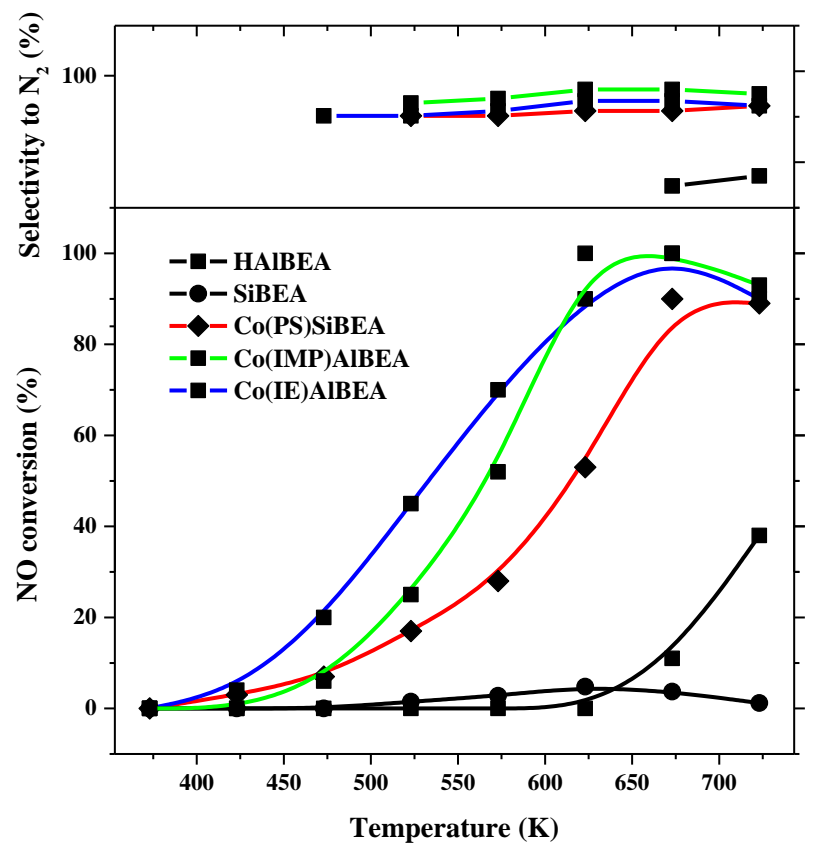

Fig. 3 


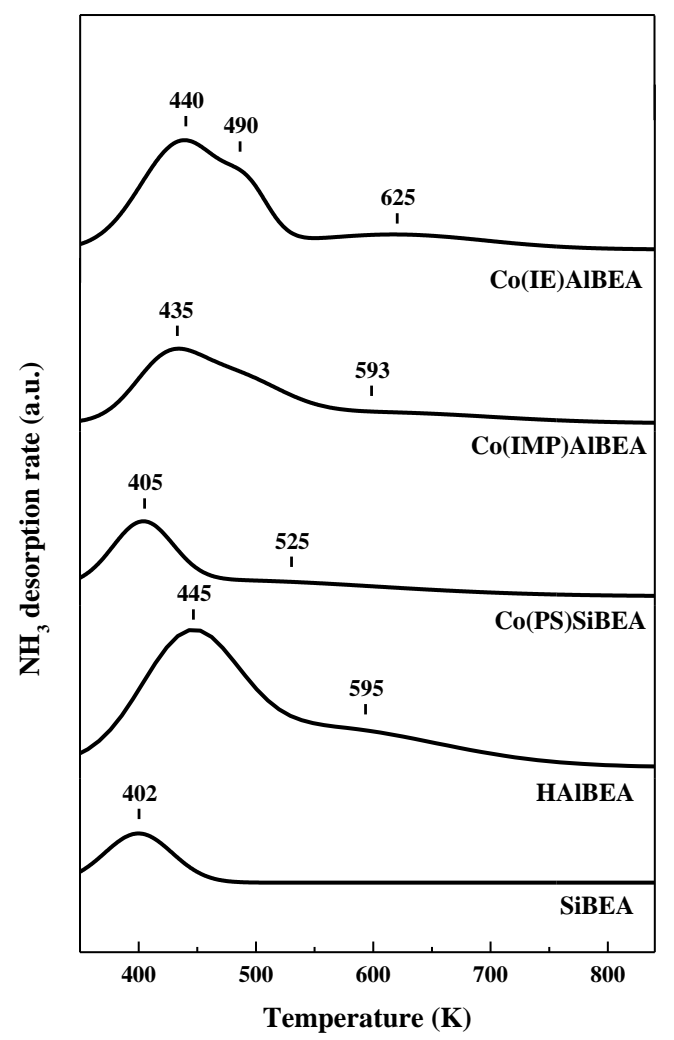

Fig. 4 


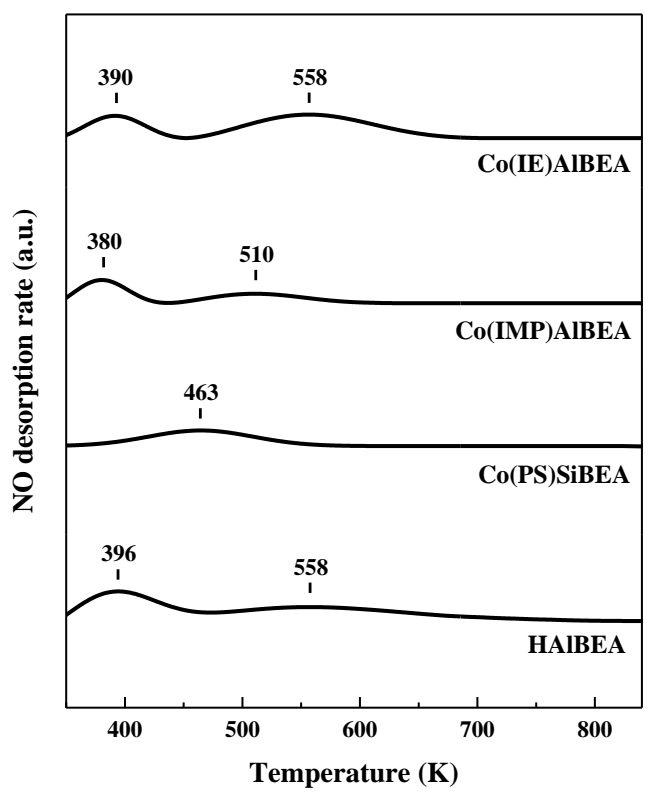

Fig. 5 

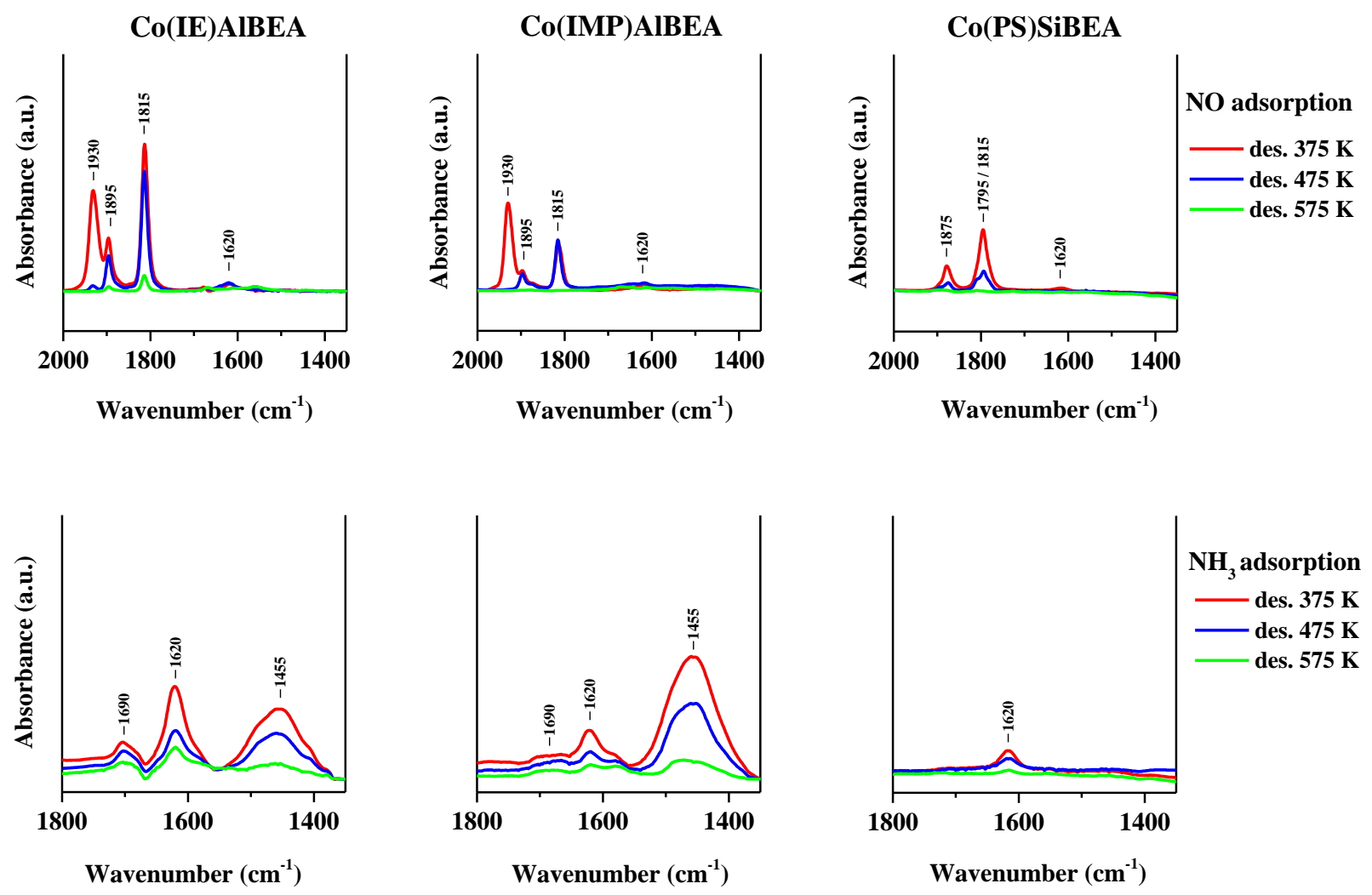

Fig. 6 

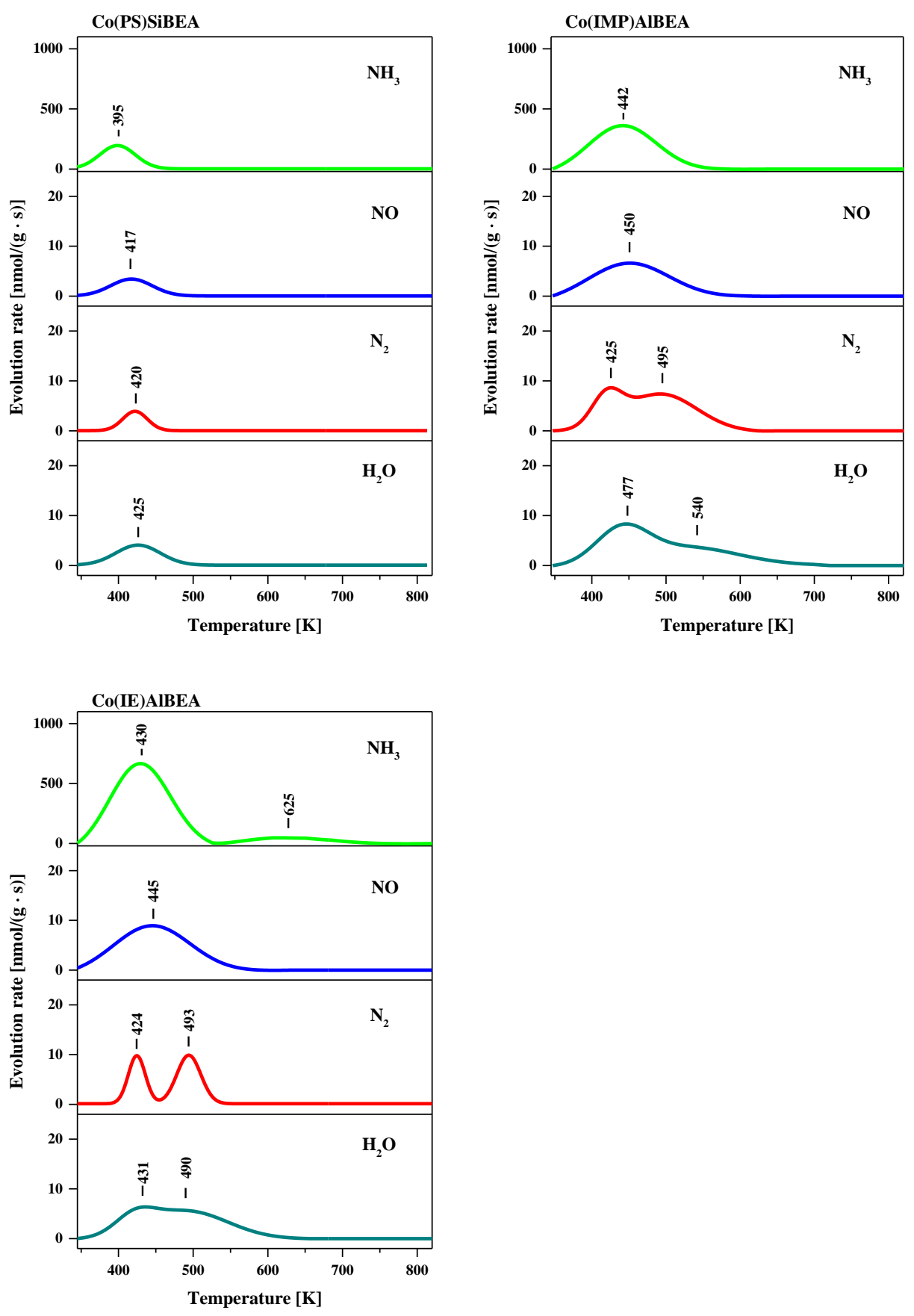

Fig. 7 

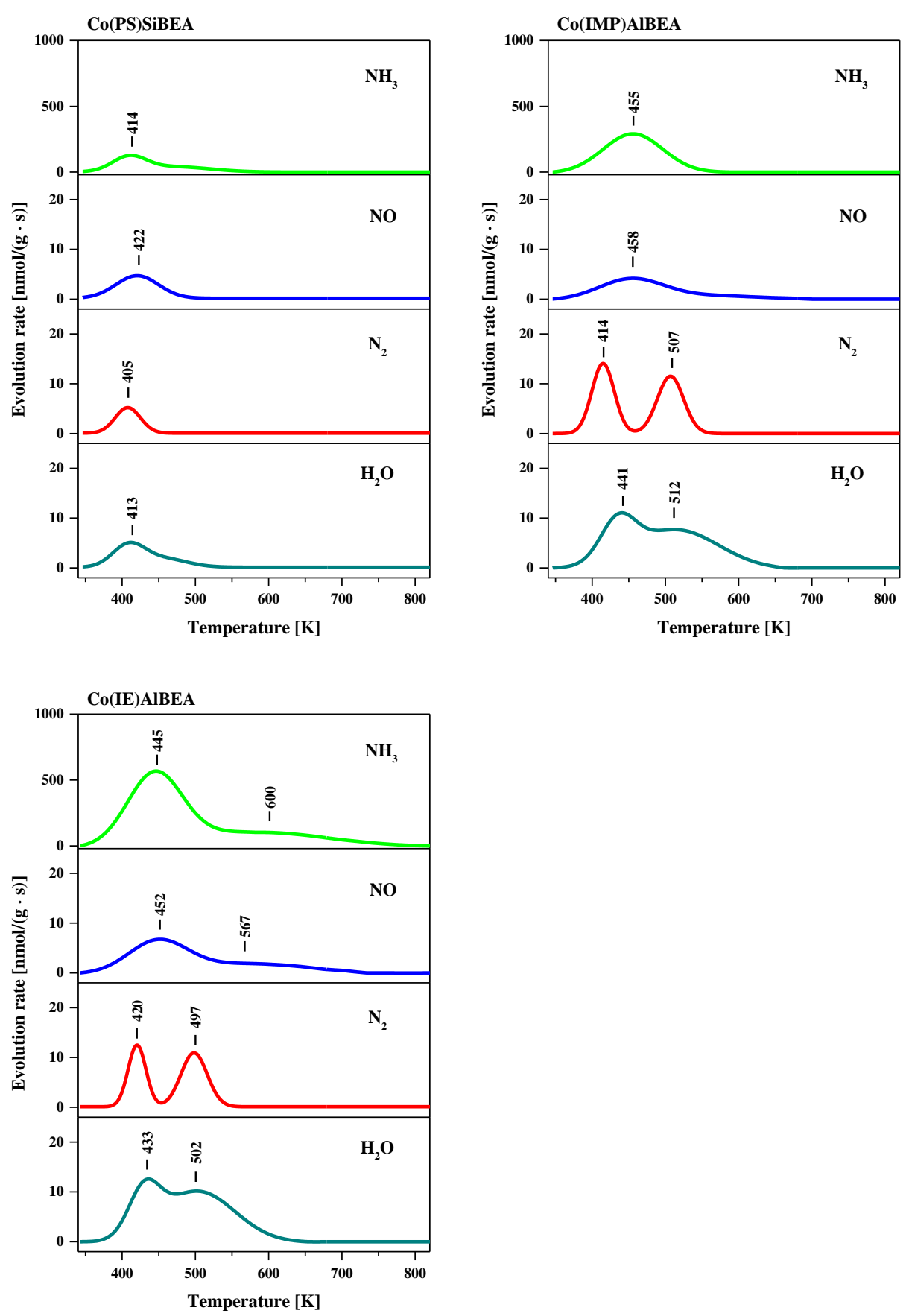

Fig. 8 


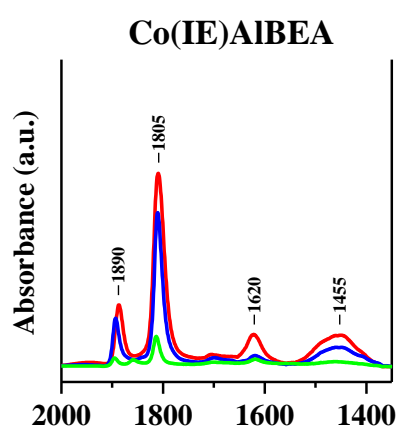

Wavenumber $\left(\mathrm{cm}^{-1}\right)$

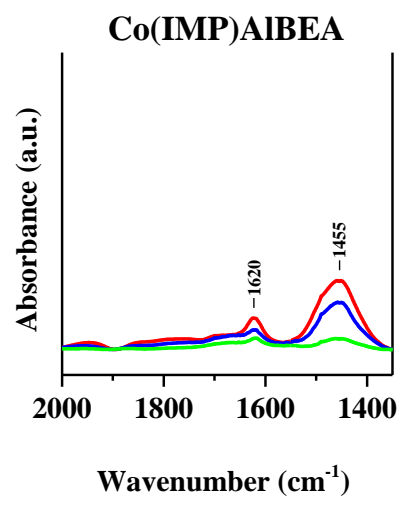

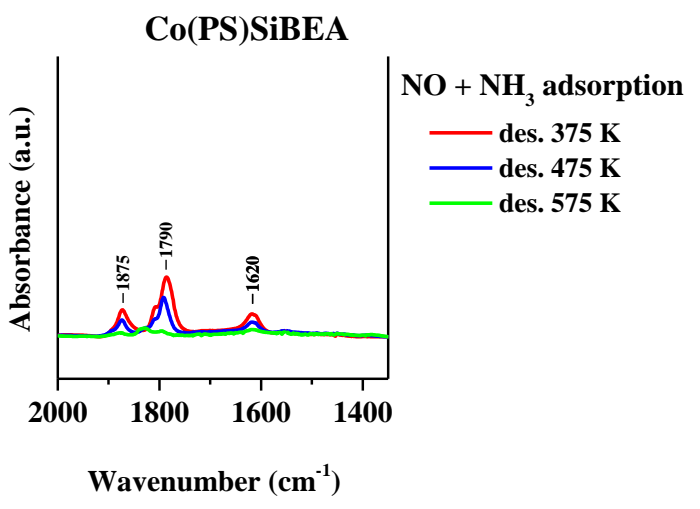

Fig. 9 


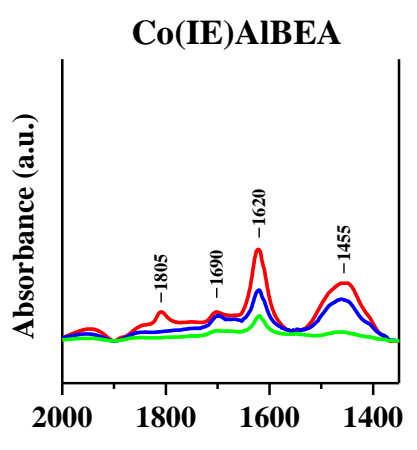

Wavenumber $\left(\mathrm{cm}^{-1}\right)$

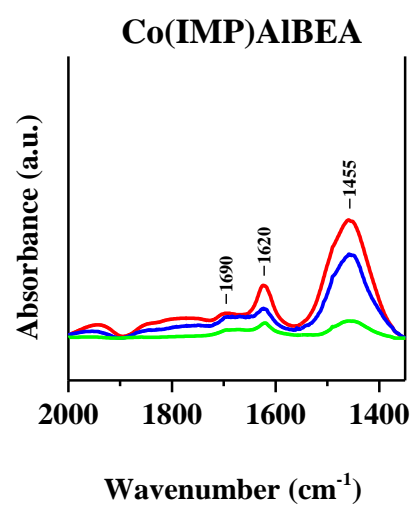

\section{Co(PS)SiBEA}

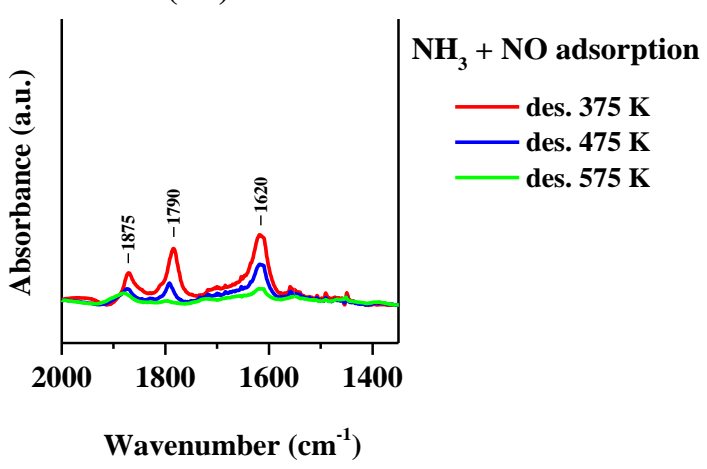

Fig. 10 

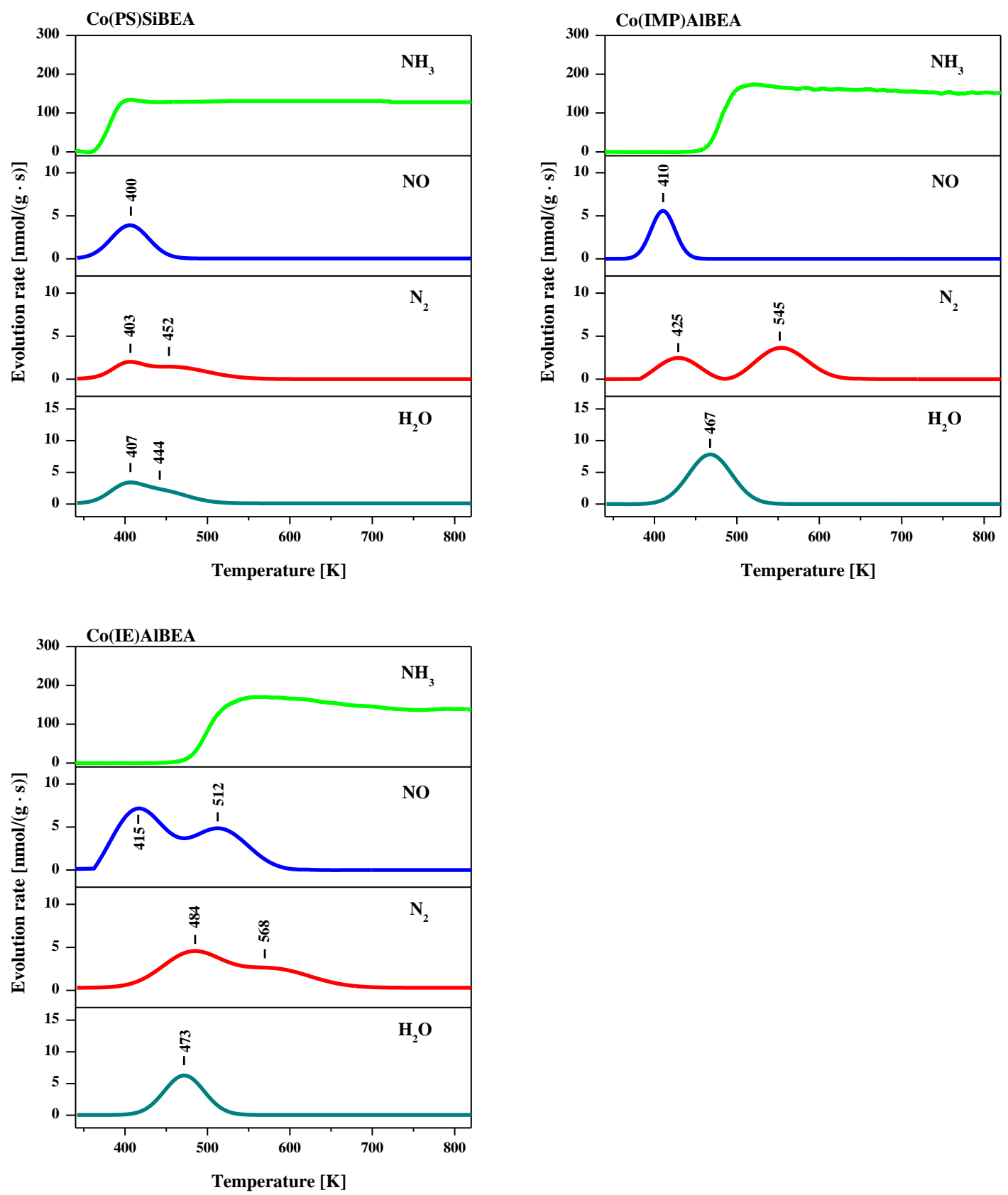

Fig. 11 

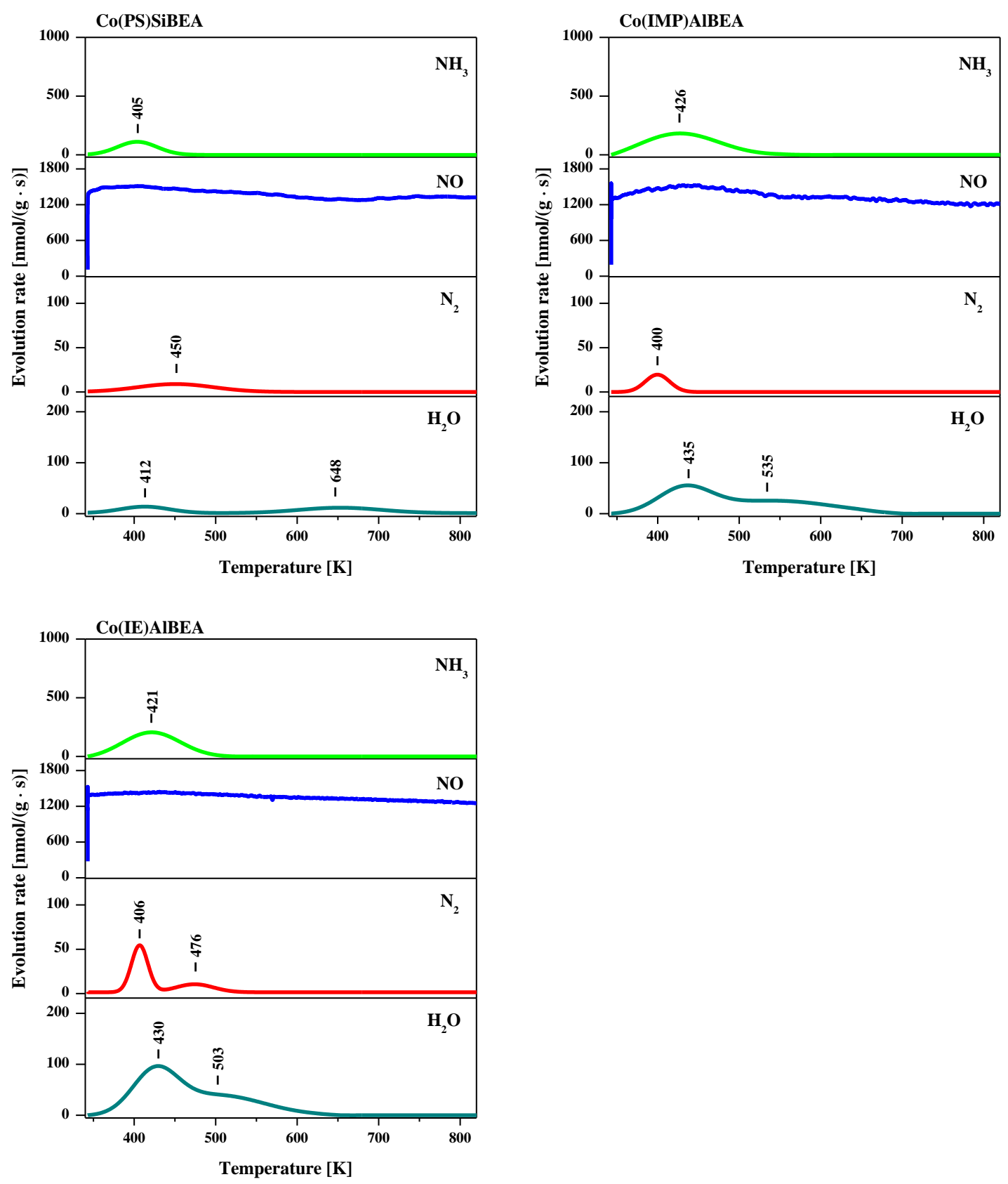

Fig. 12 

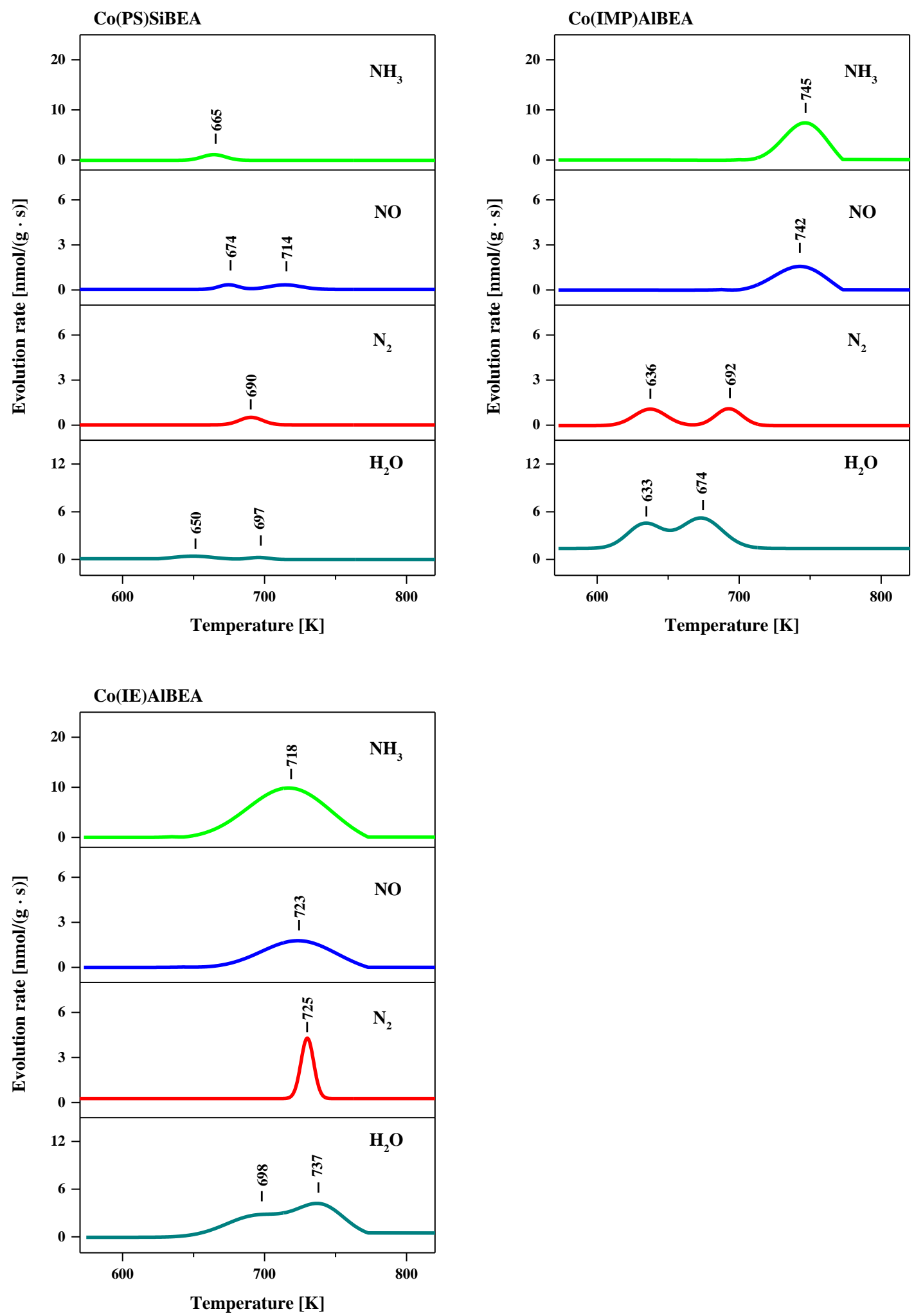

Fig. 13 
Table 1. The physicochemical properties of the HAlBEA and SiBEA supports and Co(PS)SiBEA, Co(IMP)AlBEA and Co(IE)AlBEA catalysts.

\begin{tabular}{|c|c|c|c|c|c|c|}
\hline SAMPLE & $\begin{array}{l}\text { Modification } \\
\text { method }\end{array}$ & $\begin{array}{l}\text { Position of } \\
\mathrm{d}_{302} \text { XRD } \\
\text { peak }\left(^{\circ}\right)\end{array}$ & $\begin{array}{l}\text { BET } \\
\text { surface area } \\
\left(\mathrm{m}^{2} / \mathrm{g}\right)\end{array}$ & $\begin{array}{l}\text { Micropore } \\
\text { volume } \\
\left(\mathrm{cm}^{3} / \mathrm{g}\right)\end{array}$ & $\begin{array}{l}\text { Speciation of } \\
\text { species }\end{array}$ & Co \\
\hline HAlBEA & - & 22.58 & 728 & 0.22 & - & \\
\hline SiBEA & - & 22.86 & 789 & 0.24 & - & \\
\hline Co(PS)SiBEA & $\begin{array}{l}\text { Two-step } \\
\text { postsynthesis }\end{array}$ & 22.79 & 645 & 0.21 & pseudo-Td Co(II) & \\
\hline $\begin{array}{l}\mathrm{Co}(\mathrm{IMP}) \mathrm{AlBE} \\
\mathrm{A}\end{array}$ & $\begin{array}{l}\text { Wet } \\
\text { impregnation }\end{array}$ & 22.56 & 641 & 0.21 & $\begin{array}{l}\text { pseudo-Td Co(II), } \\
\text { Oh Co(II) }\end{array}$ & \\
\hline Co(IE)AlBEA & Ion exchange & 22.56 & 649 & 0.21 & $\begin{array}{l}\text { pseudo-Td Co(II), } \\
\text { Oh } \mathrm{Co}(\mathrm{II})\end{array}$ & \\
\hline
\end{tabular}

